\title{
2D structural and thermal models in southeastern Norway based on the recently drilled Årvollskogen borehole and 2D density, magnetic and thermal modelling
}

Yuriy Petrovich Maystrenko ${ }^{*}$, Harald Kristian Elvebakk, Guri Venvik Ganerød, Ole Lutro, Odleiv Olesen and Jan Steinar Rønning

\author{
* Correspondence: \\ yuriy.maystrenko@ngu.no \\ Geological Survey of Norway (NGU), \\ P.O. Box 6315 Sluppen7491 \\ Trondheim, Norway
}

\begin{abstract}
Background: We have made an attempt to understand the main mechanism which controls the conductive heat transfer in the Årvollskogen borehole. This has been done in order to determine the 2D subsurface temperature distribution within the deep-seated crystalline rocks and, therefore, to estimate the geothermal potential in the Moss area near Oslo.

Methods: An integrated 2D density, magnetic and conductive thermal analysis has been performed in order to recognise the major structural features and thermal pattern of the crystalline crust.

Results: Based on 2D density and magnetic modelling, a 2D structural model has been constructed for the Moss area. This 2D model has been used during the 2D thermal modelling. The results of the $2 \mathrm{D}$ thermal modelling demonstrate that $\mathrm{a}$ significant decrease of the Earth's surface temperatures during the last glaciations still affects the subsurface thermal field of the study area in terms of reduced temperatures within the uppermost crystalline crust. The modelled temperatures are characterised by almost horizontal isotherms without considerable vertical disturbances, reflecting the predominance of subhorizontal layering within the crystalline crust of the Moss area.

Conclusion: The 2D density and magnetic modelling, with consideration of all available geological and structural data, allows us to reveal the deep structure of the crystalline crust within the Moss area. According to the results of the $2 \mathrm{D}$ thermal modelling, the predicted temperatures within the upper crystalline crust are in the range of expected values for this part of Fennoscandia.
\end{abstract}

Keywords: Density; Magnetic and thermal modelling; Deep structure; Subsurface temperature; Conductive heat transfer; Geothermal potential; Norway

\section{Background}

The ecological aspects of energy production permanently increase the importance of environment-friendly sources of energy, one of which is a geothermal energy. During the last decades, the Geological Survey of Norway (NGU) has studied the crustal structure and the subsurface thermal regime of Norway in terms of both direct 
measurements and modelling approaches (Ebbing et al. 2007, Olesen et al. 2007, 2013, Pascal et al. 2010a, 2010b, Slagstad 2008, Slagstad et al. 2008a, 2008b, 2009). As a result, in the spring of 2012, NGU has been asked to join Statkraft Varme AS in a research project with the goal to evaluate the geothermal potential in the town of Moss, which is located near Oslo in southeastern Norway.

An integrated lithosphere-scale, 2D density, magnetic and conductive thermal analysis has been carried out in order to understand some of the structural features and thermal pattern of the crystalline crust within the Moss area. There, the Årvollskogen borehole was drilled in the town of Moss in $2012\left(10.7^{\circ} \mathrm{E}, 59.4^{\circ} \mathrm{N}\right.$; Figure 1$)$. The 2D density, magnetic and conductive thermal analysis has been carried out along a N-Strending cross-section, called Line 1 (for location, see Figure 2). The Årvollskogen borehole has revealed the configuration of the uppermost part of the crystalline crust in the Moss area. Thermal well logging (Figure 3) was performed in this borehole at the beginning of January 2013, allowing us to constrain the thermal regime of the subsurface within the uppermost crystalline crust of Line 1 . In addition, there is the Fredrikstad borehole at $28 \mathrm{~km}$ southeast of the Årvollskogen borehole (Figures 2, 4, 5 and 6). The Fredrikstad borehole shows similar measured temperatures (Figure 3), implying that thermal field along Line 1 can be rather stable without any significant perturbations. The cross-section had purposely not been chosen to run in the geologically more

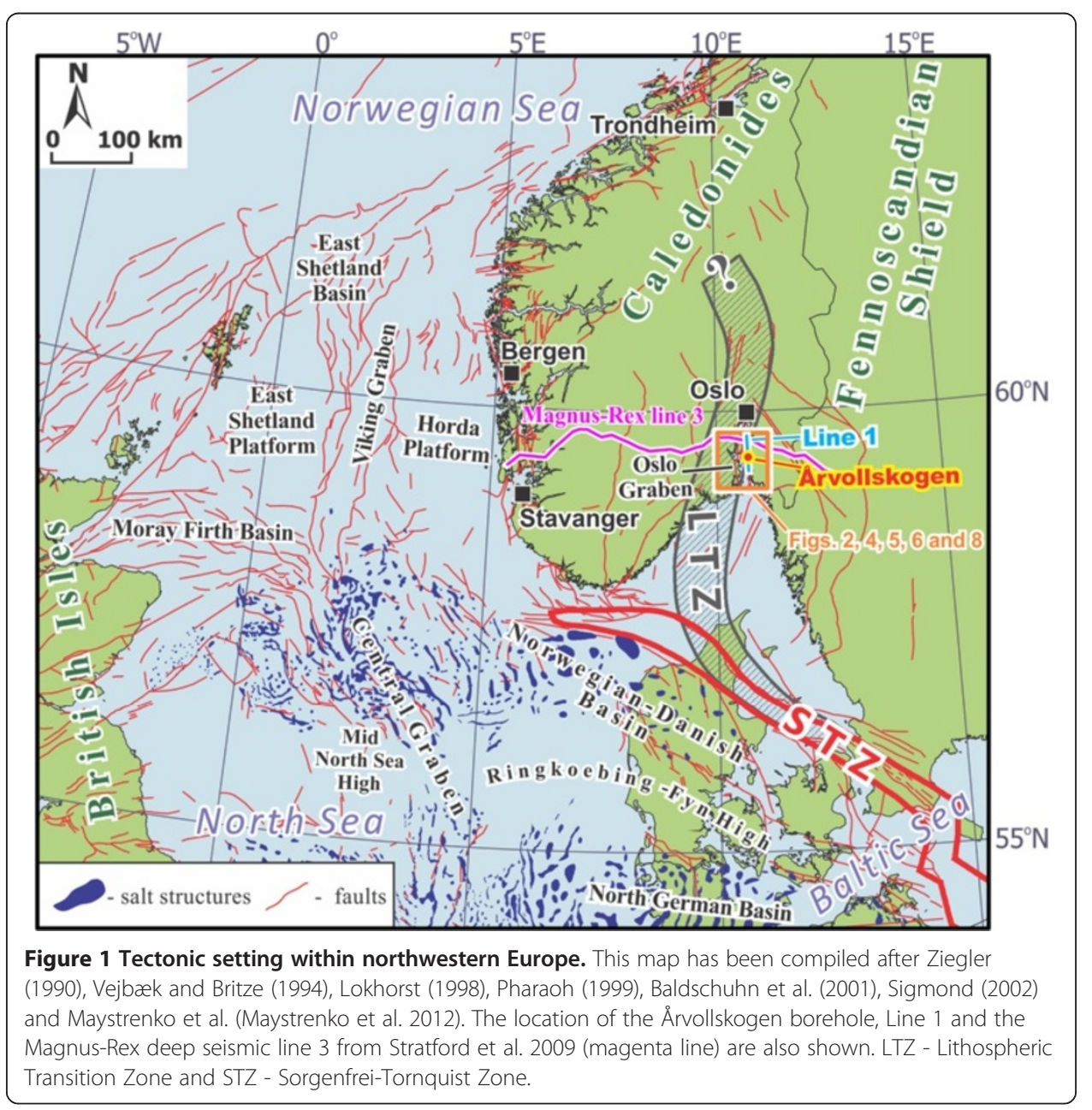




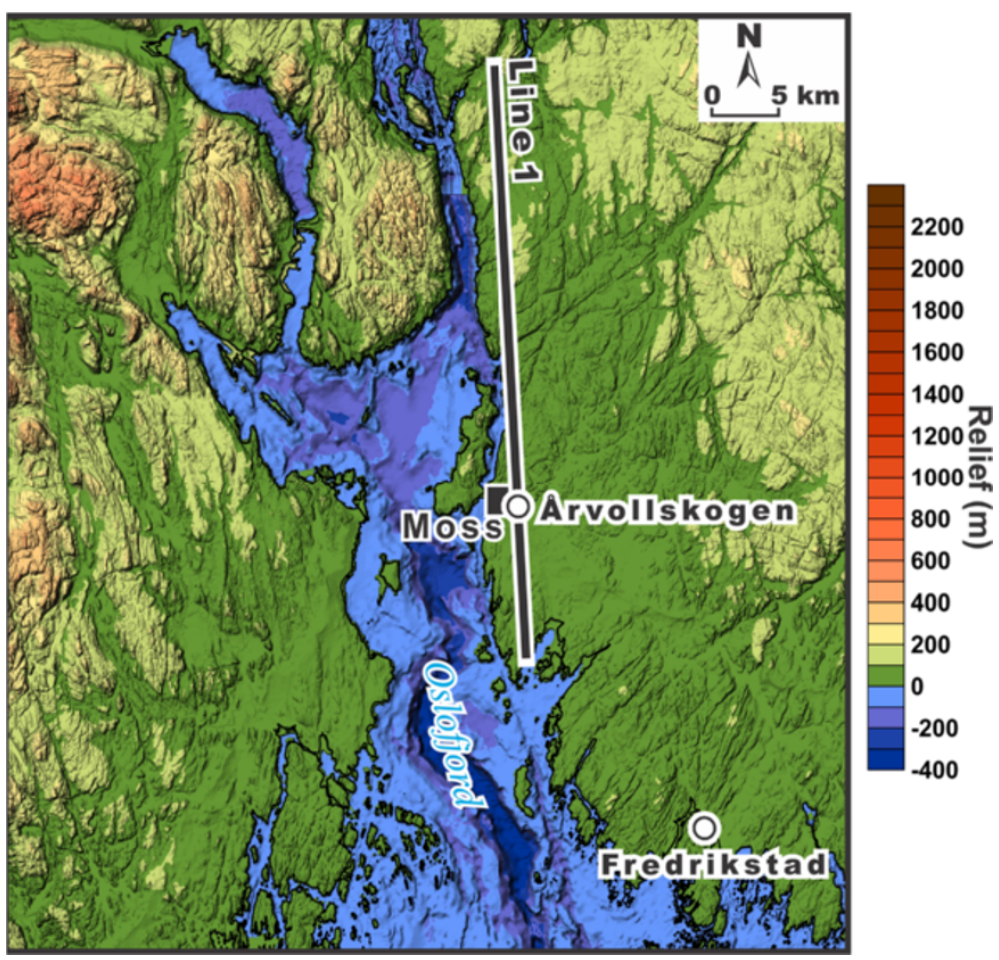

Figure 2 Bathymetry and topography within the study area (Norwegian Mapping Authority).

representative E-W direction across the major fault of the Oslo Graben due to a lack of detailed geological and gravity data offshore within the Oslofjord (Figures 4 and 5).

A total of 108 core samples from the $811 \mathrm{~m}$-deep Årvollskogen borehole have been investigated in the laboratory of NGU to obtain values of density and thermal conductivity for the upper-crustal rocks. In addition, the NGU petrophysical database, called "Petbase" (Olesen et al. 1993), provides additional measured values of densities, magnetic susceptibilities and thermal properties of crystalline rocks which are exposed at the Earth's surface within the study area.

The 2D density and magnetic modelling approach has been used to obtain a $2 \mathrm{D}$ density and magnetic model along Line 1 in order to understand the configuration of the deep structure within the study area. Furthermore, this gravity- and magneticconsistent, 2D structural model has been used to evaluate the present-day conductive thermal field beneath the study area. Therefore, the main results of our study are related to the 2D configuration of the structural and thermal pattern within the Moss area based on 2D density, magnetic and thermal modelling.

\section{Geological setting}

The topography (Figure 2) in the vicinity of the Årvollskogen borehole, which is located at 36 m.a.s.l., is mainly characterised by comparatively smoothed landforms. Changes in relief are notable only on the western side of the Oslofjord where the relief is 200$400 \mathrm{~m}$ above mean sea level. The bathymetry demonstrates that depths to the sea bottom reach more than $400 \mathrm{~m}$ within the axial parts of the Oslofjord (Figure 2). 


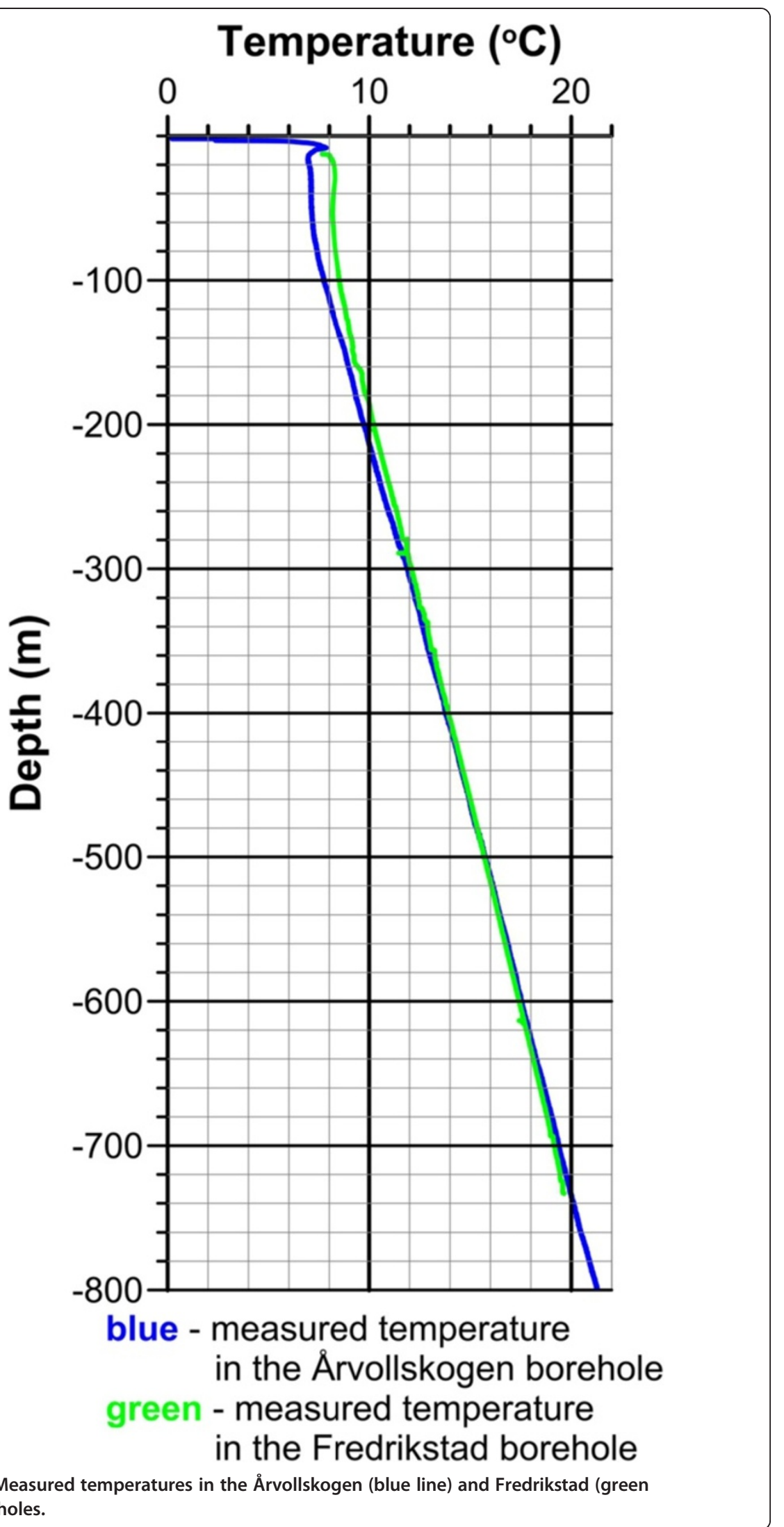




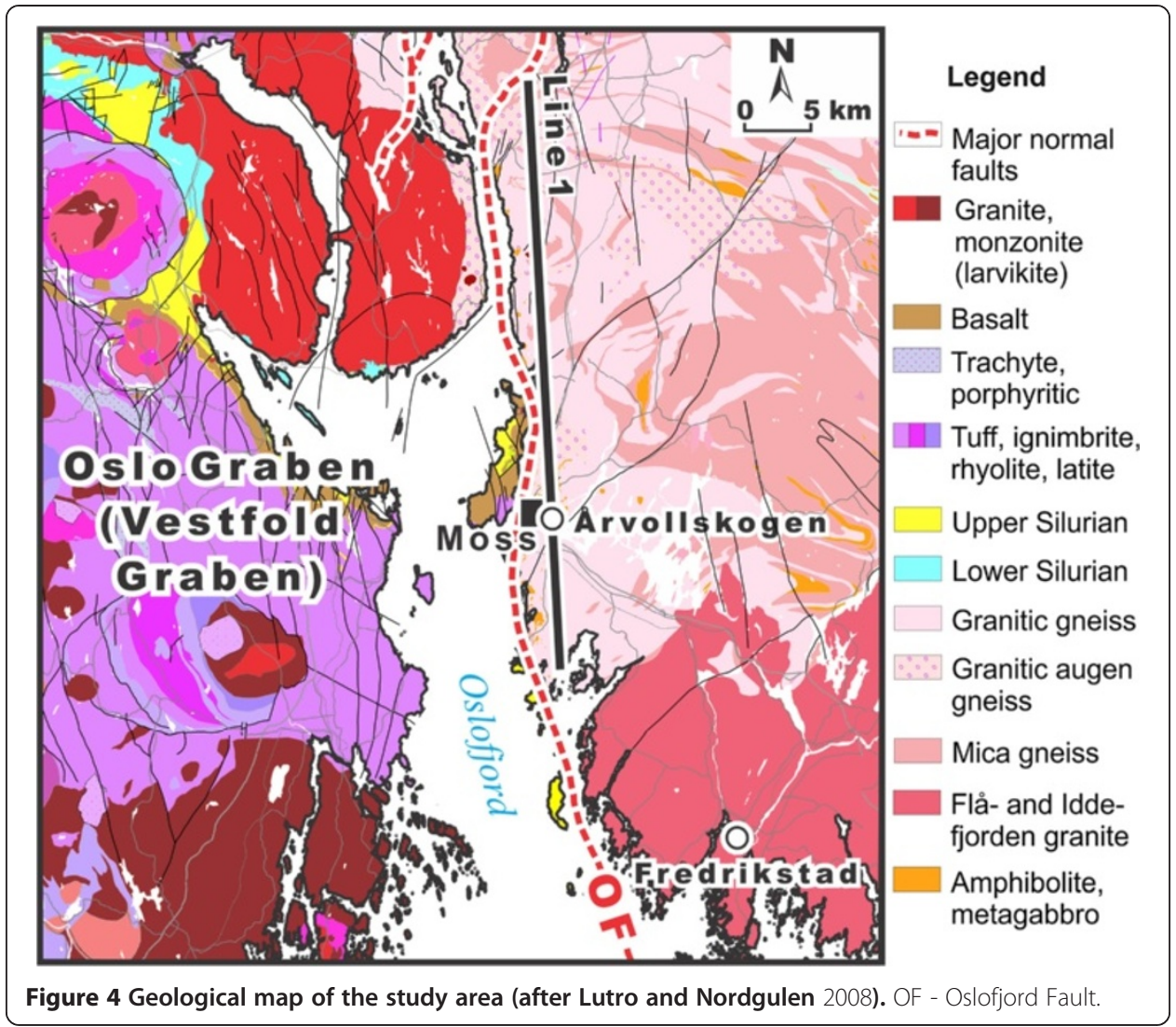

The major tectonic element of the Moss area is the Late Carboniferous-Early Permian Oslo Graben (Figure 1) which contains large volumes of plutonic and volcanic rocks (Ro et al. 1990, Heeremans and Faleide 2004). These magmatic rocks are well mapped at the surface within the Oslo Graben, whereas some local magmatic intrusions are present within the flanks of this graben structure (Figure 4; Lutro and Nordgulen 2008).

At the large scale, the Oslo Graben is situated above the lithospheric transition zone (Figure 1) which is characterised by the steep gradient of the eastward-dipping lithosphere-asthenosphere boundary (Medhus 2009, Gradmann et al. 2013). Tectonically, the Oslo Graben was affected by a major extensional event when a large part of Europe was subjected to a regional rifting event in the Late Carboniferous-Early Permian times (e.g. Heeremans and Faleide 2004). Localisation of the most prominent extensional deformation structures occurred along the major boundary fault which is located about $4 \mathrm{~km}$ west of the Årvollskogen borehole. Consequently, this NNE-SSWstriking graben is structurally bounded by extensional boundary faults. The average amount of vertical displacement is more than $500 \mathrm{~m}$ along these boundary faults (e.g. Larsen et al. 2008).

The bedrock geology of the Moss region (Lutro and Nordgulen, 2008) is shown in Figure 4. The Årvollskogen borehole is located within the eastern flank of the Vestfold Graben, which is the southern segment of the Oslo Graben. Meso- and Neoproterozoic granites and different kinds of gneisses are exposed in the Moss area (Figure 4). There are also Palaeo- and Mesoproterozoic mafic and metamorphic rocks mostly represented 


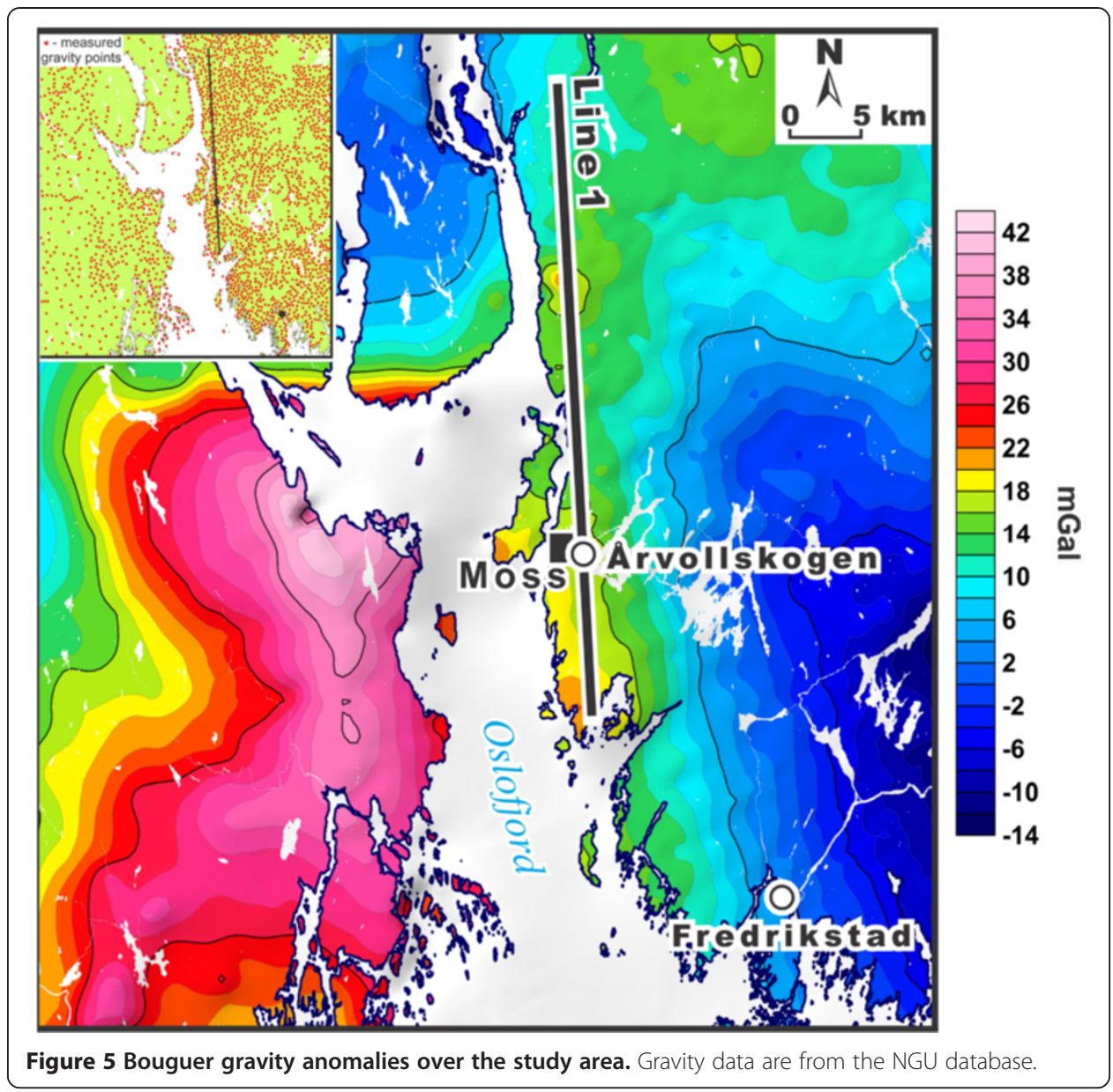

by gabbroic intrusions and amphibolites, as well as Late Carboniferous-Early Permian and Early Triassic intrusions. To the west, the Oslofjord Fault separates the PalaeoMesoproterozoic crystalline rocks of the eastern flank from the Vestfold Graben, which is filled with sedimentary rocks and the relatively thick, Upper Carboniferous-Lower Permian, synrift volcanic rocks and intrusions, including alkaline basalts, tholeiites, rhombporphyry lavas, larvikites and syenites (Figure 4; Neumann et al. 2004, Larsen et al. 2008).

The drillcore of the Årvollskogen borehole is very heterogeneous with alternations of rocks of different lithologies. For that reason, the borehole section has been subdivided based only on the dominant lithologies at different depth intervals (Figure 7). The upper interval of 70$350 \mathrm{~m}$ of the drillcore is characterised by amphibolites and subordinate metagabbro, whereas below that down to slightly more than $755 \mathrm{~m}$ of the drillcore, rocks are mainly represented by granitic to quartz-dioritic mica gneisses and mica gneisses with interlayers of granitic pegmatites. Amphibolites with minor metagabbro constitute the deepest c. $50 \mathrm{~m}$ of the drillcore.

\section{Methods}

\section{Observed gravity and magnetic anomalies}

A detailed Bouguer gravity anomaly map from the NGU database (Gellein et al. 1993, Olesen et al. 2010) has been used in our study (Figure 5). This map of the Moss area has been compiled by use of more than 5000 measured gravity points with a station spacing over land areas between 500 and $3000 \mathrm{~m}$. 


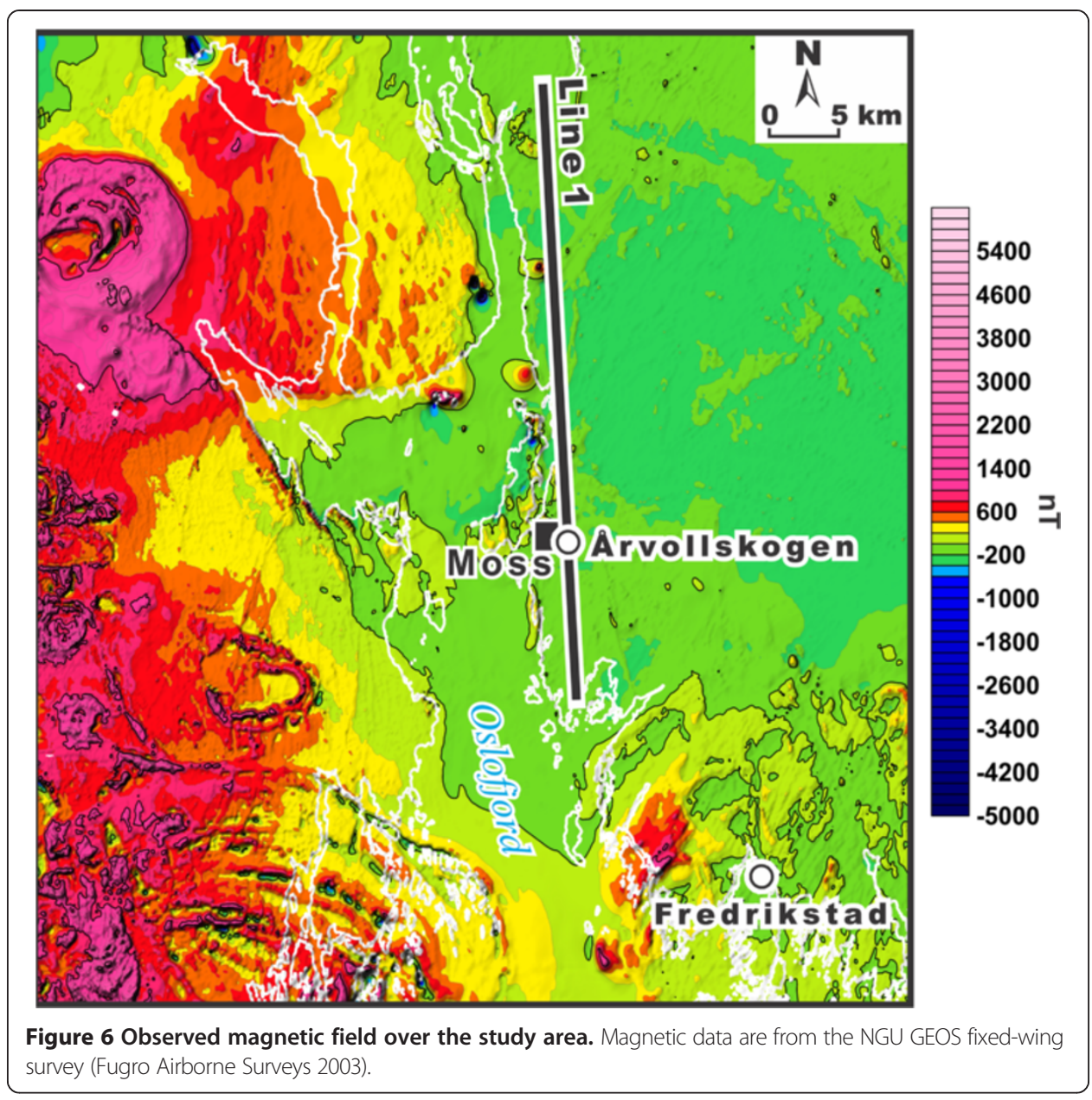

The most prominent feature of the observed gravity field over the investigated area (Figure 5) is the presence of a wide positive gravity anomaly over the western side of the Oslofjord. This NE-SW-trending anomaly is located over the axial part of the Oslo Graben. The observed gravity field along Line 1 is characterised by a NW-SE-trending positive anomaly in the south, which is possibly an eastern continuation of the previously mentioned regional gravity anomaly. In addition, a short-wavelength positive gravity anomaly is observed along the northern part of Line 1 (Figure 5).

The observed magnetic field over the study area (Figure 6) has been extracted from the NGU GEOS fixed-wing survey which was carried out in 2003 in the Oslo region by Fugro Airborne Surveys (Pty) Limited (Fugro Airborne Surveys 2003). The total magnetic field is referred to the International Geomagnetic Reference Field (IGRF).

The most pronounced feature of the observed magnetic field is related to the highamplitude magnetic anomalies over the western part of the map shown in Figure 6. These prominent positive magnetic anomalies are spatially coincident with the distribution of the Late Carboniferous-Early Permian, extrusive and intrusive/igneous rocks (cf. Figures 4 and 6). Along Line 1, several short-wavelength magnetic anomalies are present, indicating a locally inhomogeneous composition of the crystalline crust within the study area. 


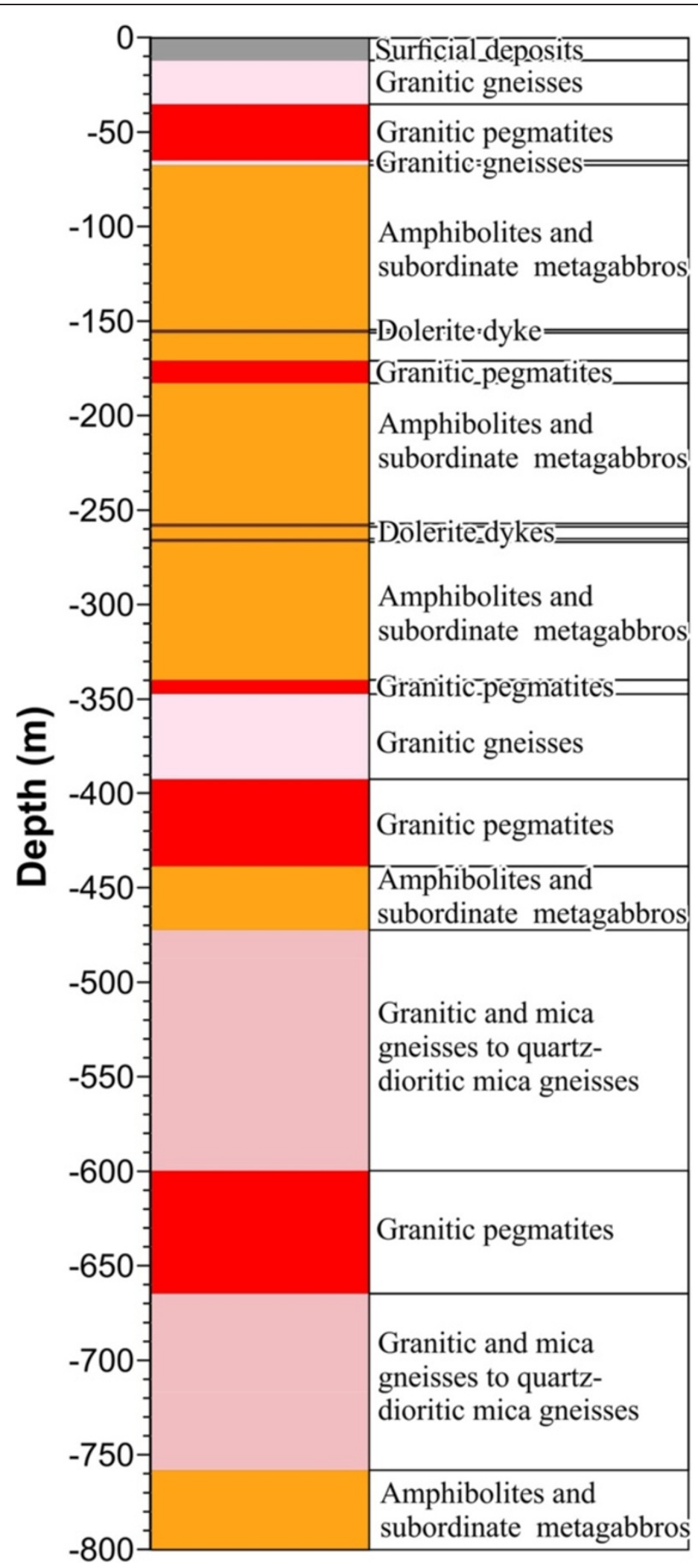

Figure 7 Lithological subdivision of the Årvollskogen borehole. Dominant lithologies are indicated by different colors (modified after Rønning et al. 2013). 


\section{Structural data}

Configuration of the deep crystalline crust within the Moss area is based on the results of forward modelling ray-tracing solutions along Line 3 of the Magnus-Rex deep seismic refraction experiment across southern Norway (see Magnus-Rex Line 3 in Figure 1; Stratford et al. 2009, Stratford and Thybo 2011). Along the Magnus-Rex Line 3, the structure of the crust is characterised by almost horizontal layering with a local uplift of the major crustal boundaries beneath the Oslo Graben (Stratford et al. 2009, Stratford and Thybo 2011).

In contrast, the structure of the upper crystalline crust is based on the surface geology (Figure 4) extrapolated to great depth and also borehole data.

The Moho topography has been adopted from Stratford et al. (2009) who have recently constructed a Moho map beneath southern Norway and southwestern Sweden based on all available deep seismic lines. The extracted part of this regional-scale map is shown in detail in Figure 8a, and reveals that the Moho topography is relatively flat along Line 1.

The lithosphere-asthenosphere boundary beneath the study area (Figure 8b) has been derived from a 3D integrated geophysical modelling study by Gradmann et al. (2013), who used the lithospheric geometry from published data sets (Calcagnile 1982, Artemieva 2006, Ebbing et al. 2012) with adjustments applied to the depth of the lithosphere in order to match seismic velocity constraints. According to the map in Figure 8b, the depth to the lithosphereasthenosphere boundary is characterised by a steep gradient in the vicinity of Line 1 .

\section{Densities, magnetic and thermal properties}

The adjusted values of the density, magnetic susceptibility, thermal conductivity, specific heat capacity and radiogenic heat production are shown in Table 1.

The upper-crustal densities and magnetic susceptibilities are generally taken from NGU's petrophysical database, "Petbase". The average constant values of upper-crustal densities and magnetic susceptibilities for each layer have been assigned according to the location of the sampling points. In addition, densities within the upper crust have been obtained by laboratory measurements of drillcore samples at NGU. The assigned upper-crustal densities vary in the range $2640-2695 \mathrm{~kg} / \mathrm{m}^{3}$. The density for the uppermiddle crystalline crust is $2740 \mathrm{~kg} / \mathrm{m}^{3}$ on average. The middle-lower crystalline crust is characterised by an average density of $2830 \mathrm{~kg} / \mathrm{m}^{3}$. A high-velocity lower crustal layer is characterised by velocities which exceed 6700-6800 m/s (Stratford et al. 2009, Stratford and Thybo 2011). As a result, the average density of this high-velocity layer has been taken to be $3056 \mathrm{~kg} / \mathrm{m}^{3}$. In addition, a density of $2940 \mathrm{~kg} / \mathrm{m}^{3}$ has been chosen for the high-density middle crust. Besides, a marked velocity change from 7100-7400 m/s within the lowest crust to more than $8000-8300 \mathrm{~m} / \mathrm{s}$ within the uppermost mantle occurs at the Moho (Stratford et al. 2009, Stratford and Thybo 2011). This prominent change in P-velocities indicates a distinct increase of densities within the uppermost mantle compared to the lower crust. Considering the thermal state of the lithospheric mantle, an average density of the lithospheric mantle has been taken to be around $3222 \mathrm{~kg} / \mathrm{m}^{3}$. The assigned densities of the crystalline rocks (Table 1 ) are generally consistent with previous gravity studies within this region (Ebbing et al. 2007, Maystrenko and Scheck-Wenderoth 2013) and are in the range of the empirical velocity-density relationship according to Barton (1986). 


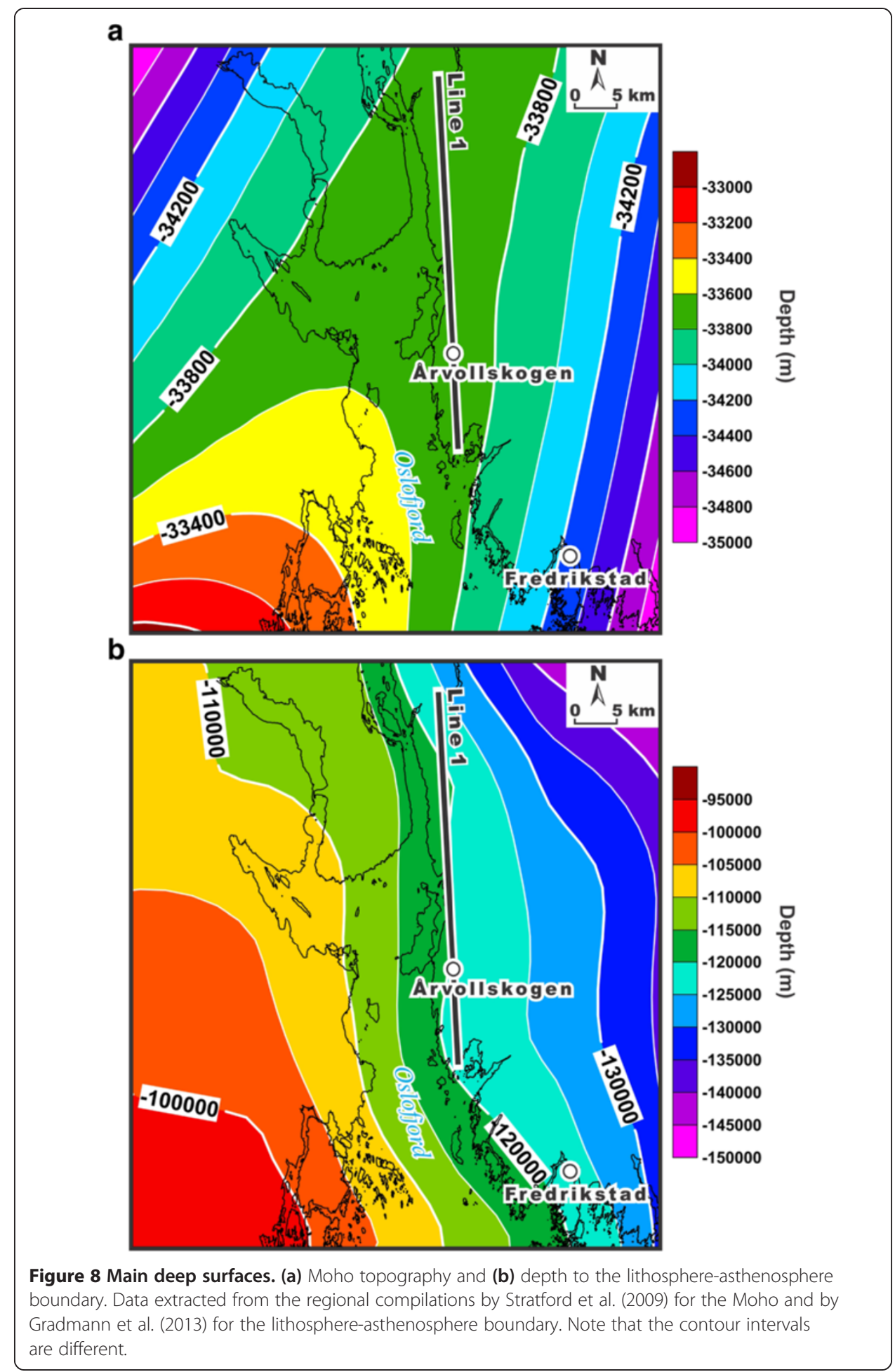

Magnetic susceptibilities for the middle-lower crystalline crust are adopted from the estimations published by Fichler et al. (2011) and Ebbing et al. (2007).

Thermal properties (specific heat capacity and thermal conductivity) within the upper crust of the study area have been obtained by laboratory measurements of drillcore samples at NGU. The distribution of the measured thermal conductivities on core 
Table 1 Densities, magnetic susceptibilities and thermal properties (specific heat capacity, thermal conductivity and radiogenic heat production) of the layers within the Moss area used during the 2D density, magnetic and thermal modelling $\left(\mathrm{k}_{\mathrm{r}}\right.$ is the thermal conductivity at room temperature)

\begin{tabular}{|c|c|c|c|c|c|}
\hline $\begin{array}{l}\text { Layer of the } 2 \mathrm{D} \\
\text { structural } \\
\text { model }\end{array}$ & $\begin{array}{l}\text { Density } \\
\rho(\mathrm{kg} / \\
\left.\mathrm{m}^{3}\right)\end{array}$ & $\begin{array}{l}\text { Magnetic } \\
\text { susceptibility } \\
X_{m}(\mathrm{SI})\end{array}$ & $\begin{array}{l}\text { Thermal conductivity } \\
\text { scale value } k_{\mathrm{r}}(\mathrm{W} / \\
\mathrm{mK})\end{array}$ & $\begin{array}{l}\text { Specific heat } \\
\text { capacity } C_{p}(J / \\
\text { kgK) }\end{array}$ & $\begin{array}{l}\text { Radiogenic heat } \\
\text { production } S(\mu \mathrm{W} / \\
\left.\mathrm{m}^{3}\right)\end{array}$ \\
\hline Gabbro & 2950 & $0.03-0.09$ & 2.90 & 780 & 0.4 \\
\hline Pyroxenite & 3100 & 0.07 & 4.00 & 780 & 0.4 \\
\hline $\begin{array}{l}\text { Amphibolite and } \\
\text { metagabbro }\end{array}$ & $\begin{array}{l}2850- \\
3050\end{array}$ & $0.001-0.06$ & 2.90 & 790 & 1.2 \\
\hline $\begin{array}{l}\text { Granitic to } \\
\text { quartzdioritic } \\
\text { gneiss }\end{array}$ & $\begin{array}{l}2654- \\
2683\end{array}$ & $0.00003-0.0095$ & 3.00 & 800 & 4.4 \\
\hline $\begin{array}{l}\text { Granitic augen } \\
\text { gneiss }\end{array}$ & $\begin{array}{l}2640- \\
2695\end{array}$ & $0.0001-0.01$ & 3.05 & 800 & 2.7 \\
\hline Mica gneiss & $\begin{array}{l}2645- \\
2670\end{array}$ & $0.0007-0.008$ & 3.05 & 800 & 2.1 \\
\hline $\begin{array}{l}\text { Upper/middle } \\
\text { crystalline crust }\end{array}$ & 2740 & 0.001 & 3.10 & 930 & 1.6 \\
\hline $\begin{array}{l}\text { Lower/middle } \\
\text { crystalline crust }\end{array}$ & 2830 & 0.001 & 3.20 & 1050 & 0.7 \\
\hline $\begin{array}{l}\text { High-density } \\
\text { crust }\end{array}$ & 2940 & 0.003 & 3.10 & 1050 & 0.3 \\
\hline $\begin{array}{l}\text { High-density } \\
\text { lower crustal } \\
\text { layer }\end{array}$ & 3056 & 0.006 & 2.85 & 1100 & 0.25 \\
\hline $\begin{array}{l}\text { Lithospheric } \\
\text { upper mantle }\end{array}$ & 3222 & - & 4.79 & 1200 & 0.03 \\
\hline
\end{tabular}

samples with depth is shown in Figure 9. Moving average values of 20 and $100 \mathrm{~m}$ have been applied to all samples with the exception of two samples with a thermal conductivity higher than $4 \mathrm{~W} / \mathrm{mK}$. According to the averaging, most of the measured values are around $3 \mathrm{~W} / \mathrm{mK}$ in the upper part of the borehole and slightly higher (around $3.3 \mathrm{~W} / \mathrm{mK}$ on average) within the lower part, reflecting the predominance of amphibolites and metagabbros at a depth interval of 100-350 m and gneisses with pegmatites at depths between 500 and $750 \mathrm{~m}$. In particular, the measured thermal conductivity of amphibolites varies from 2.3 to $3.94 \mathrm{~W} / \mathrm{mK}$, whereas the thermal conductivity of gneisses and pegmatites are in the ranges of $2.26-3.92$ and $2.02-4.87 \mathrm{~W} / \mathrm{mK}$, respectively. Moreover, four measurements show that thermal conductivity varies from 3.05 to $3.83 \mathrm{~W} / \mathrm{mK}$ in the case of dolerites (diabases). Only three samples of breccia have been measured and gave values in range of 3.2-3.96 W/mK.

In this study, the thermal conductivities of rocks have been set to be updated during the modelling in response to changes in calculated temperatures. This has been done in order to monitor changes in the thermal conductivities due to increasing temperature with depth.

Temperature-dependent values of the thermal conductivities for the uppermost crust have been calculated according to the empirical equations (1) and (2) from Sass et al. (1992):

$$
\mathrm{k}(\mathrm{T})=\mathrm{k}_{\mathrm{o}} /\left(1.007+\mathrm{T}\left(0.0036-0.0072 / \mathrm{k}_{\mathrm{o}}\right)\right)
$$




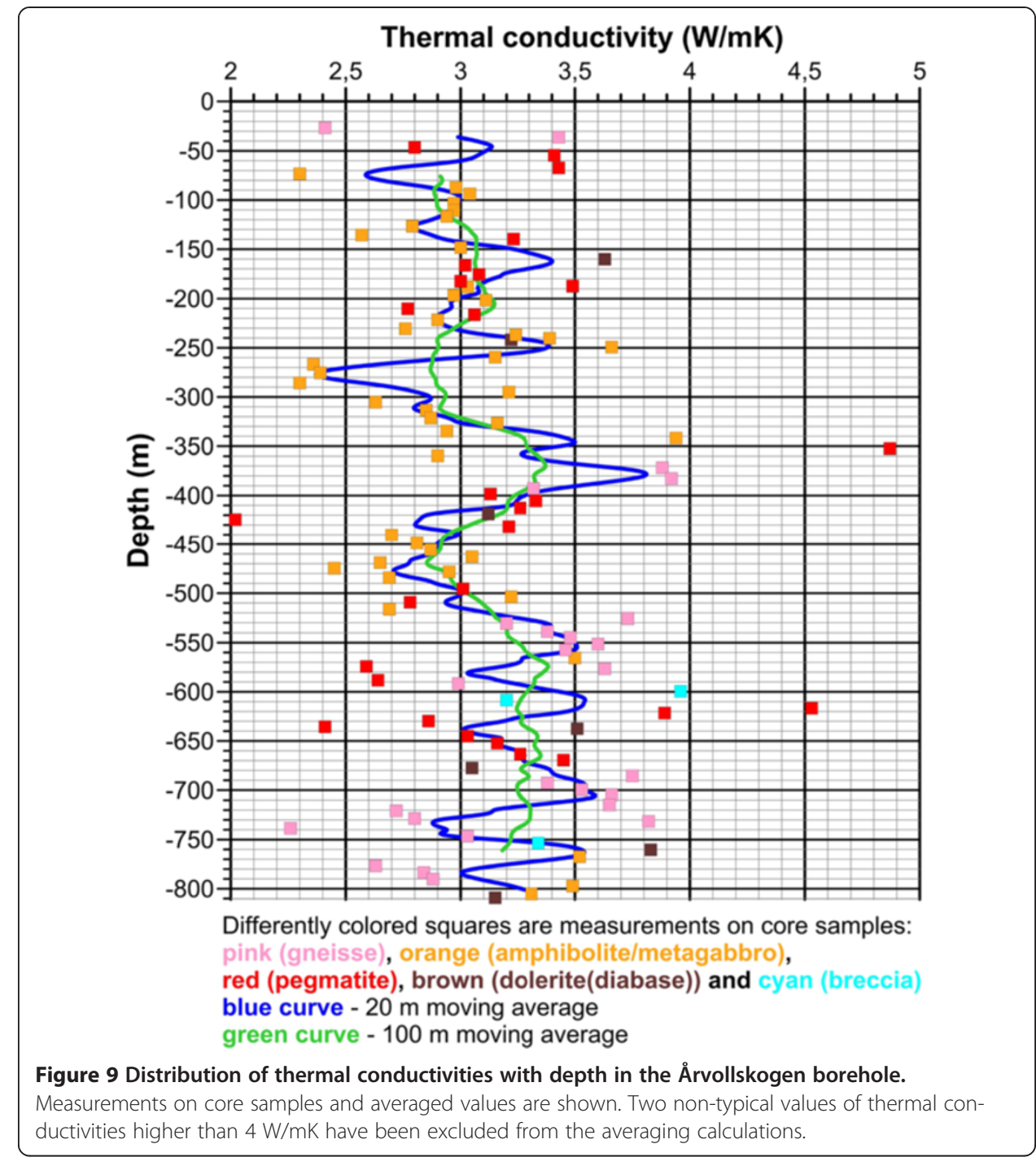

$$
\mathrm{k}_{\mathrm{o}}=\mathrm{k}_{\mathrm{r}}\left(1.007+25\left(0.0037-0.0074 / \mathrm{k}_{\mathrm{r}}\right)\right)
$$

where $\mathrm{k}(\mathrm{T})$ is the thermal conductivity $[\mathrm{W} / \mathrm{mK}]$ at temperature $\mathrm{T}$ in $\left[{ }^{\circ} \mathrm{C}\right], \mathrm{k}(0)$ is the thermal conductivity $[\mathrm{W} / \mathrm{mK}]$ at $0^{\circ} \mathrm{C}, \mathrm{k}_{\mathrm{r}}$ is the thermal conductivity $[\mathrm{W} / \mathrm{mK}]$ at room temperature of $25^{\circ} \mathrm{C}$ and $\mathrm{T}$ is the temperature $\left[{ }^{\circ} \mathrm{C}\right]$.

The empirical equations (3) and (4) from Vosteen and Schellschmidt (2003) have been used to calculate the temperature-dependent thermal conductivities for the rest of the crystalline crust where temperatures are higher than $300^{\circ} \mathrm{C}$ :

$$
\begin{aligned}
& \mathrm{k}(\mathrm{T})=\mathrm{k}_{\mathrm{o}} /\left(0.99+\mathrm{T}\left(\mathrm{a}-\mathrm{b} / \mathrm{k}_{\mathrm{o}}\right)\right) \\
& \mathrm{k}_{\mathrm{o}}=0.53 \mathrm{k}_{\mathrm{r}}+1 / 2\left(1.13\left(\mathrm{k}_{\mathrm{r}}\right)^{2}-0.42 \mathrm{k}(25)\right)^{1 / 2}
\end{aligned}
$$

where $\mathrm{k}(\mathrm{T})$ is the thermal conductivity $[\mathrm{W} / \mathrm{mK}]$ at temperature $\mathrm{T}[\mathrm{K}], \mathrm{k}_{\mathrm{o}}$ is the thermal conductivity $[\mathrm{W} / \mathrm{mK}]$ at $0^{\circ} \mathrm{C}, \mathrm{k}_{\mathrm{r}}$ is the thermal conductivity $[\mathrm{W} / \mathrm{mK}]$ at room temperature of $25^{\circ} \mathrm{C}$, $\mathrm{T}$ is the temperature $[\mathrm{K}]$, a and $\mathrm{b}$ are constants which vary within the following range: $\mathrm{a}=0.0030 \pm 0.0015$ and $\mathrm{b}=0.0042 \pm 0.0006$. 
To define the temperature- and pressure-dependent thermal conductivities within the lithospheric mantle, the empirical equations (5) and (6) from Hofmeister (1999) have been used:

$$
\begin{aligned}
& \mathrm{k}(\mathrm{T}, \mathrm{P})=\mathrm{k}_{\mathrm{r}}(298 / \mathrm{T})^{\mathrm{a}} \exp [-(4 \gamma+1 / 3) \alpha(\mathrm{T}-298)]\left(1+\mathrm{K}_{\mathrm{o}}^{\prime} \mathrm{P} / \mathrm{K}_{\mathrm{o}}\right)+\mathrm{k}_{\mathrm{rad}} \\
& \mathrm{k}_{\mathrm{rad}}=4.7\left(0.01753-0.00010365 \mathrm{~T}+2.2451 \mathrm{~T}^{2} / 10^{7}-3.407 \mathrm{~T}^{3} / 10^{11}\right)
\end{aligned}
$$

where $\mathrm{k}(\mathrm{T}, \mathrm{P})$ is thermal conductivity $[\mathrm{W} / \mathrm{mK}]$ at temperature $\mathrm{T}[\mathrm{K}]$ and under pressure $[\mathrm{Pa}], \mathrm{k}_{\mathrm{r}}$ is the thermal conductivity $[\mathrm{W} / \mathrm{mK}]$ at room temperature, $\mathrm{T}$ is the temperature $[\mathrm{K}], \gamma$ is Grueneisen parameter $(\gamma=1$ to 1.4$)$, a is the phonon fitting parameter ( $\mathrm{a}=0.25$ to 0.45$), \alpha(\mathrm{T}-298)$ is the volume coefficient of thermal expansion as a function of temperature, $\mathrm{K}_{\mathrm{o}}$ is the bulk modulus $[\mathrm{Pa}]\left(\mathrm{K}_{\mathrm{o}}=261 \mathrm{GPa}\right), \mathrm{K}_{\mathrm{o}}^{\prime}$ is the pressure derivative of the bulk modulus $\left(\mathrm{K}_{\mathrm{o}}^{\prime}=5\right)$ and $\mathrm{k}_{\mathrm{rad}}$ is the radiative component of the thermal conductivity, enhanced according to van den Berg et al. (2001).

The assigned radiogenic heat production of the upper-crustal layers is based on the average values which are calculated from airborne gamma spectrometry surveys (heat generation map of the Oslo Region in Pascal et al. 2010) and/or obtained from average heat-production rates for geological units in Norway according to rock sample measurements (Slagstad 2008, Slagstad et al. 2009). In addition, the results of gamma spectrometry logging in the Årvollskogen borehole have been used to obtain values of the radiogenic heat production derived from uranium $(\mathrm{U})$, thorium $(\mathrm{Th})$ and potassium $(\mathrm{K})$ concentrations. The relationship between radiogenic heat production and concentrations of the radiogenic elements (7) from Rybach (1988) has been used to calculate the radiogenic heat production of upper-crustal rocks.

$$
\mathrm{S}=\rho\left(9.52 \mathrm{C}_{\mathrm{U}}+2.56 \mathrm{C}_{\mathrm{Th}}+3.48 \mathrm{C}_{\mathrm{K}}\right) * 10^{-5}
$$

where $S$ is the radiogenic heat production $\left[\mu \mathrm{W} / \mathrm{m}^{3}\right], \rho$ is the density $\left[\mathrm{kg} / \mathrm{m}^{3}\right], \mathrm{C}_{\mathrm{U}}$ and $\mathrm{C}_{\mathrm{Th}}$ are the concentrations of $\mathrm{U}$ and $\mathrm{Th}$ in ppm, and $\mathrm{C}_{\mathrm{K}}$ is the concentration of $\mathrm{K}$ in wt.\%.

The obtained radiogenic heat production in the Årvollskogen borehole varies mainly from 0.5 to more than $8 \mu \mathrm{W} / \mathrm{m}^{3}$ (Figure 10). These values clearly correlate with the predominant lithology. There is a clear difference in the calculated radiogenic heat production between the upper part of the borehole's section where amphibolites and metagabbro predominate and the lower part of the borehole where granitic to quartzdioritic gneisses are mainly present. Amphibolites are characterised by $1.2-1.5 \mu \mathrm{W} / \mathrm{m}^{3}$ on average, whereas the radiogenic heat production of granitic to quartzdioritic gneisses is much higher, reaching more than $8 \mu \mathrm{W} / \mathrm{m}^{3}$ locally (Figure 10). An average value of $4.4 \mu \mathrm{W} / \mathrm{m}^{3}$ has been assigned to the upper-crustal granitic gneisses, assuming that radiogenic heat production decreases with depth. Local peaks with very high values of the calculated radiogenic heat production are mostly related to the intervals where pegmatites are particularly abundant.

The values of thermal properties for the lithospheric mantle, and the middle and lower crystalline crust are inferred from the results of measurements of rock samples with similar lithological composition (Čermak and Rybach 1982, Clauser 2011). In addition, the assigned thermal properties of the crystalline crust and the lithospheric mantle have been compared with published values from Wollenberg and Smith (1987), Hofmeister (1999), Artemieva et al. (2006) and Scheck-Wenderoth and Maystrenko (2008, 2013). It should be mentioned that the derived density, magnetic susceptibility, 


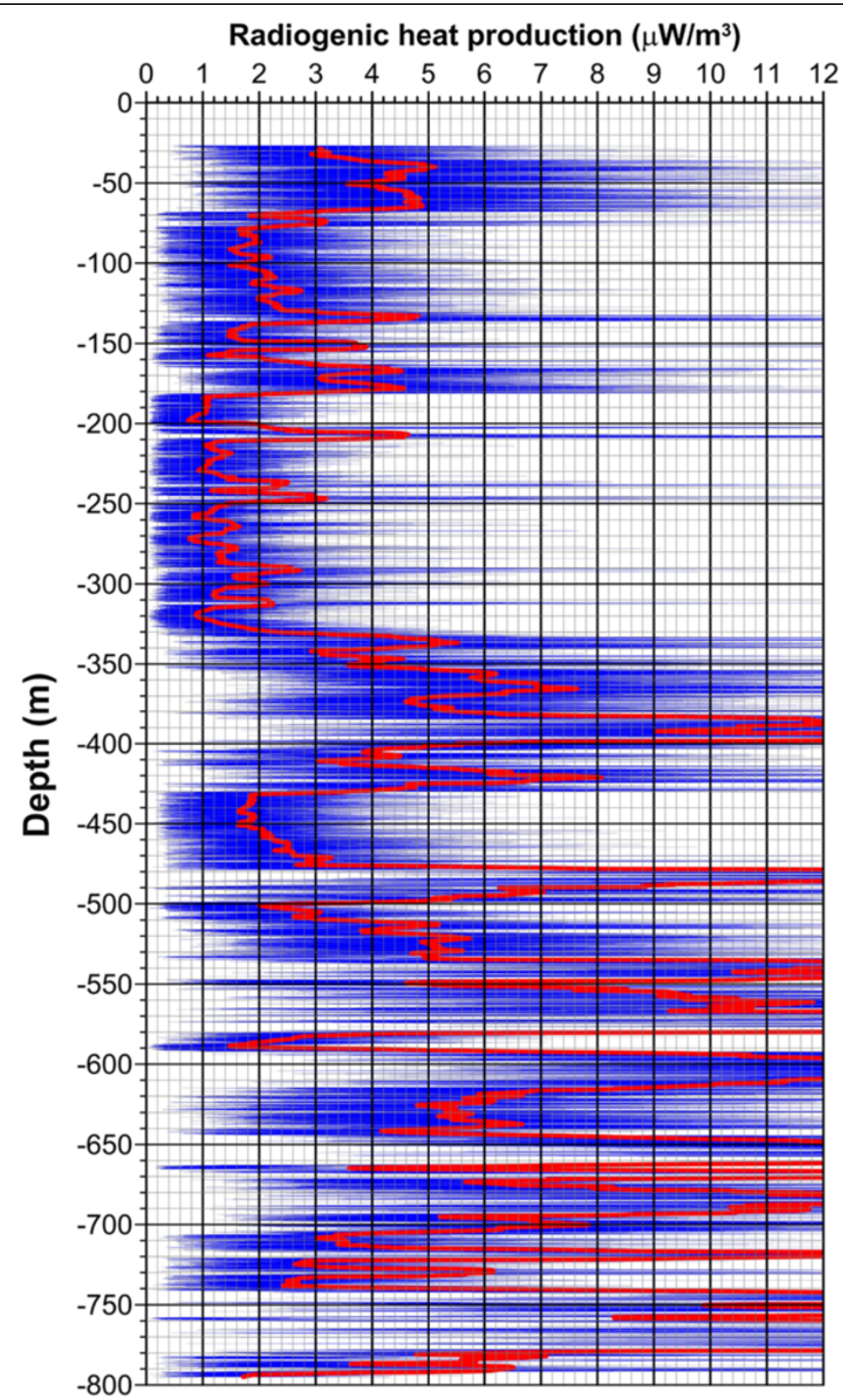

Figure 10 The radiogenic heat production of rocks in the Årvollskogen borehole based on a gamma spectrometry logging. Radiogenic heat production has been calculated according to Rybach (1988). The blue plot is the radiogenic heat production obtained from the gamma spectrometry logging, and the red one is calculated by use of running-mean averages at depth intervals of $5 \mathrm{~m}$.

specific heat capacity and radiogenic heat production have been set to be constant for each layer (Table 1).

\section{Methodology}

The 2D density, magnetic and thermal modelling have been applied to understand the present-day deep structure and thermal state of the crystalline crust within the Moss area. 
The 2D density and magnetic modelling have been carried out by use of the commercial software package Geosoft Oasis montaj. During this modelling, the GM-SYS Profile Modelling module has been used to model the structure of the crystalline crust along a 2D profile (Line 1 in Figures 2, 4, 5 and 6) by interactive changes of the geometries, densities and magnetic properties of the layers, in order to obtain a fit between the observed gravity and magnetic anomalies and the modelled gravity and magnetic responses of the 2D structural model. The advantage of the GM-SYS Profile Modelling is that a great number of 2D layers/bodies with any polygonal shape can be used to simulate the deep structure within the study area. This means that any geometrical complexity of the geological structure can be accurately represented and examined during the 2D density and magnetic modelling. Therefore, GM-SYS Profile Modelling allows us to create a complex 2D structural model which is consistent with both the observed gravity and magnetic fields.

A 2D temperature distribution has been calculated with the help of the commercial software package COMSOL Multiphysics, which is a finite-element analysis software for a variety of physical processes.

During the 2D thermal modelling, the Heat Transfer Module has been used to simulate the stationary and time-dependent heat transfer in solids by heat conduction, which is assumed to be the dominant mechanism of heat transfer at the regional scale within the study area. Therefore, these simulations have been carried out based on physical principles of the conductive 2D thermal field by solving the heat equation (8):

$$
\rho C(\delta \mathrm{T} / \delta \mathrm{t})=\nabla \cdot(\mathrm{k} \nabla \mathrm{T})+\mathrm{Q}
$$

where $\rho$ is the density $\left[\mathrm{kg} / \mathrm{m}^{3}\right], \mathrm{C}$ is the heat capacity $[\mathrm{J} / \mathrm{kgK}], \mathrm{T}$ is the temperature $[\mathrm{K}], \mathrm{k}$ is the thermal conductivity $[\mathrm{W} / \mathrm{mK}], \nabla \mathrm{T}$ is the temperature gradient $[\mathrm{K} / \mathrm{m}], \mathrm{t}$ is the time $[\mathrm{s}], \mathrm{Q}$ is the heat source (radioactive heat production) $\left[\mathrm{W} / \mathrm{m}^{3}\right], \delta \mathrm{T}$ is the change in temperature per time interval $\delta$ t, and $\nabla$. is the operator giving the spatial variation in temperature.

The heat flow $\mathrm{q}\left[\mathrm{W} / \mathrm{m}^{2}\right]$ has been calculated according to Fourier's law of heat conduction:

$$
\mathrm{q}=-\mathrm{k} \nabla \mathrm{T}
$$

where $\mathrm{k}$ is the thermal conductivity $[\mathrm{W} / \mathrm{mK}]$ and $\nabla \mathrm{T}$ is the temperature gradient $[\mathrm{K} /$ $\mathrm{m}]$.

The 2D thermal modelling has been performed by means of a finite-element method in $2 \mathrm{D}$ which is a suitable approach for a relatively complex geological structure. Free triangular elements with different size have been used for the mesh. The mesh has been set to be more detailed within the upper part of the model compared to the deeper part. The reason for this is related to the fact that the resolved structure is relatively detailed within the upper crust.

The solution of the heat equation (8) is sensitive to the thermal boundary conditions. The lateral boundaries are closed to heat transfer, assuming that the temperature gradient is zero across the thermally insulated lateral boundaries. The base of the lithosphere (Figure $8 \mathrm{~b}$ ) has been chosen as a lower thermal boundary, which corresponds to the $1300^{\circ} \mathrm{C}$ isotherm (Turcotte and Schubert 2002). For the upper boundary, the annual 
average air temperature and time-dependent palaeotemperatures at the Earth's surface (Figure 2) have been applied.

\section{Palaeoclimatic corrections}

The 2D thermal modelling has been carried out considering the palaeoclimatic changes of the surface temperature during the last 228,000 years before present (BP). During this time interval, the Moss area was affected by glaciations during the Saalian glacial/Eemian interglacial period (220,000-110,000 years BP) and the Weichselian glacial period $(\sim 110,000$ 10,000 years BP), as well as by the Holocene interglacial period (10,000 years BP to present day). The present-day temperature at the Earth's surface has been taken from the database at the Norwegian Meteorological Institute (Tveito et al. 2000) and is $6.2^{\circ} \mathrm{C}$.

The palaeotemperature at 8000 years $\mathrm{BP}$ has been assumed to be about $1^{\circ} \mathrm{C}$ below the present-day average air temperature. The difference between the present-day temperature and the temperature at 8000 years BP has been inferred from the reconstructed, areaaverage, mean annual temperature anomalies for northwestern Europe (Davis et al. 2003).

To reconstruct the older palaeoclimatic history, a recently constructed model of temporal ice-cover variations within the Scandinavian peninsula during the Weichselian glacial period (Olsen 2006, Slagstad et al. 2009, Olsen et al. 2013) has been used. Figure 11 shows the limits of the ice sheet through time (10,500-110,000 years BP; reproduced from Slagstad et al. 2009) over southern Scandinavia with the location of the Årvollskogen borehole. At times when the study area was glaciated, a temperature of $-0.5^{\circ} \mathrm{C}$ is assumed at the Earth's surface beneath the ice sheet. This is similar to the assumption used by Slagstad et al. (2009) for palaeoclimatic corrections of heat-flow measurements from several sites in Norway. A near-melting point temperature of around $0^{\circ} \mathrm{C}$ is in agreement with published estimates of the subglacial thermal regime beneath the large polar ice sheets in Antarctica (Pattyn 2010), which can be taken as comparable analogues of ice sheets developed during the Quaternary glacial cycles in Europe. In contrast, a different scenario has been used for time intervals when the Moss area was free of ice or close to the limit of the ice sheet (Figure 11). Mean annual temperatures of $-5^{\circ} \mathrm{C}$ within the Moss area during the Younger Dryas (Renssen and Isarin 1998) have been taken as representative temperatures at the Earth's surface for 12,000 years BP and for the time when the borehole site was ice free or located close to the edge of the ice cap.

The Weichselian glacial ( 110,000-10,000 years BP) and Holocene interglacial (10,000 years BP to present day) palaeoclimatic settings were also applied for the Saalian glacial/Eemian interglacial period (220,000-110,000 years BP), assuming that climatic conditions were similar during the Weichselian glacial/Holocene interglacial and the Saalian glacial/Eemian interglacial periods (Andersen and Borns 1994, Slagstad et al. 2009). The summarised changes of palaeotemperatures during the Weichselian glacial/Holocene interglacial and Saalian glacial/Eemian interglacial periods are shown in Figure 12 and Table 2. This scenario has been applied during the time-dependent 2D conductive thermal modelling. It should be mentioned that the temperature used for the ice-free time steps is derived from the results of modelling of mean annual temperatures for the Younger Dryas (Renssen and Isarin 1998) and can theoretically vary in the range of $\pm 8^{\circ} \mathrm{C}$ (Figure 12 and Table 2) during the Weichselian and Saalian glacial periods. 


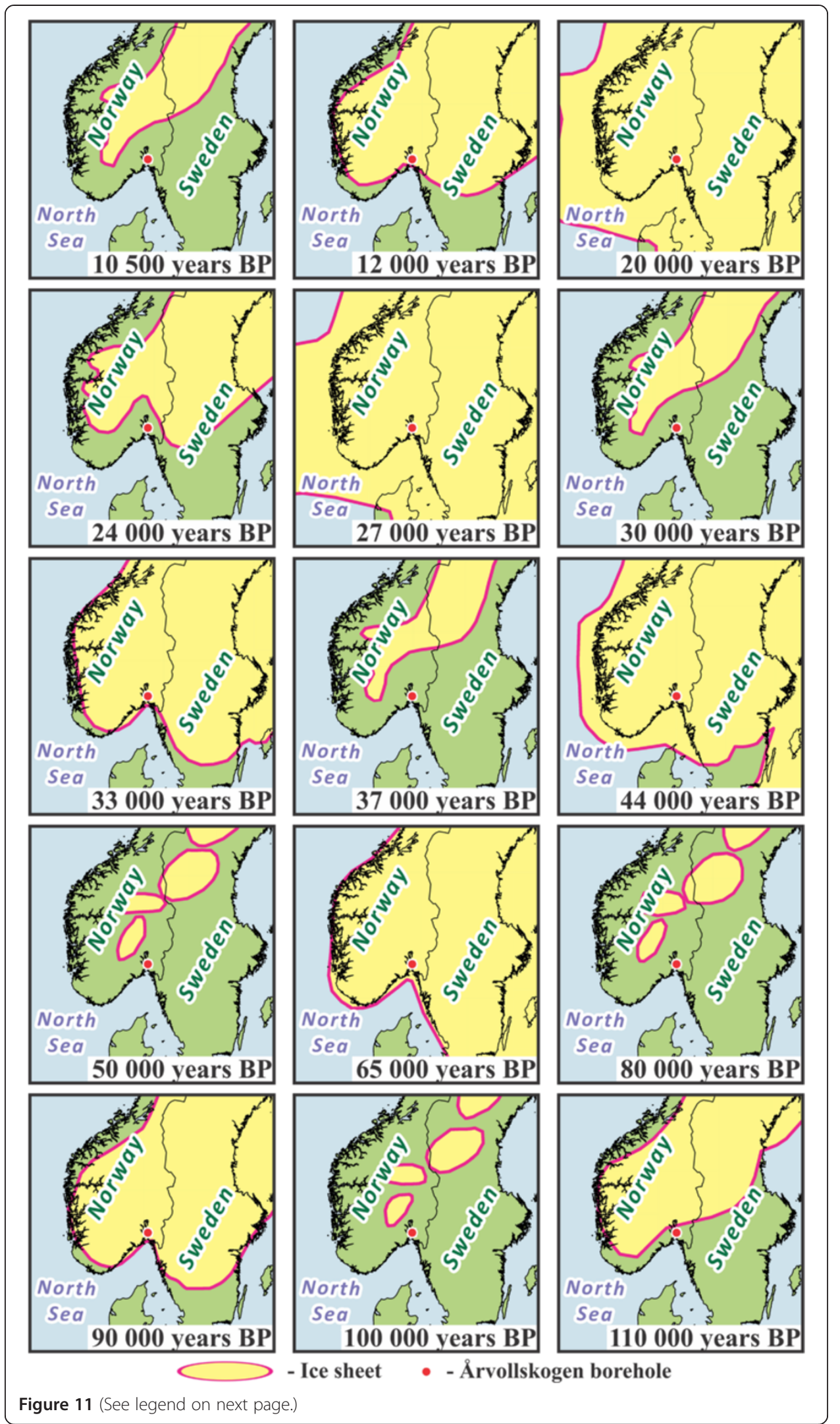


(See figure on previous page.)

Figure 11 Ice cover during the Weichselian glaciation in southern Scandinavia with location of the Årvollskogen borehole. Limits of ice cover at different time steps are simplified after Olsen (2006),

Slagstad et al. (2009) and Olsen et al. (2013). The location of the Årvollskogen borehole is shown by the red circle.

\section{Results and discussion}

Results of 2D crustal (2D density and magnetic) modelling

The 2D density and magnetic analyses have been applied along Line 1 (for location see Figures 2, 4, 5 and 6) to reveal the major structural features of the crystalline crust in the vicinity of the Årvollskogen borehole. Results of the 2D density and magnetic modelling demonstrate that the upper crystalline crust is not so homogeneous laterally (Figure 13). In contrast, layers of the middle-lower crust are almost horizontal, reflecting the subhorizontal distribution of the velocities along the Magnus-Rex deep seismic Line 3 (Stratford et al. 2009, Stratford and Thybo 2011), which is situated slightly to the north of the Moss area (Figure 1).

On the regional scale, there is a gradual increase in the observed gravity within the southern part of Line 1 (Figure 13). According to the results of the 2D density modelling, this regional-scale positive gravity anomaly is related to the presence of the highdensity zone within the middle crust (the violet body in Figure 13) which can be at least partially associated with the basin-scale positive gravity anomaly over the axial part of the Oslo Graben (Figure 5). On the other hand, this regional gravity anomaly does not really correlate with the series of high-amplitude positive magnetic anomalies over the western part of the Oslo region (c.f. Figures 4 and 6) and therefore, to some extent, these anomalies could have a different origin.

An obvious correlation between the high-amplitude magnetic anomalies and areas underline by the Upper Carboniferous-Lower Permian magmatic rocks (c.f. Figures 4 and 6) indicates an upper-crustal origin for the positive magnetic anomalies over the

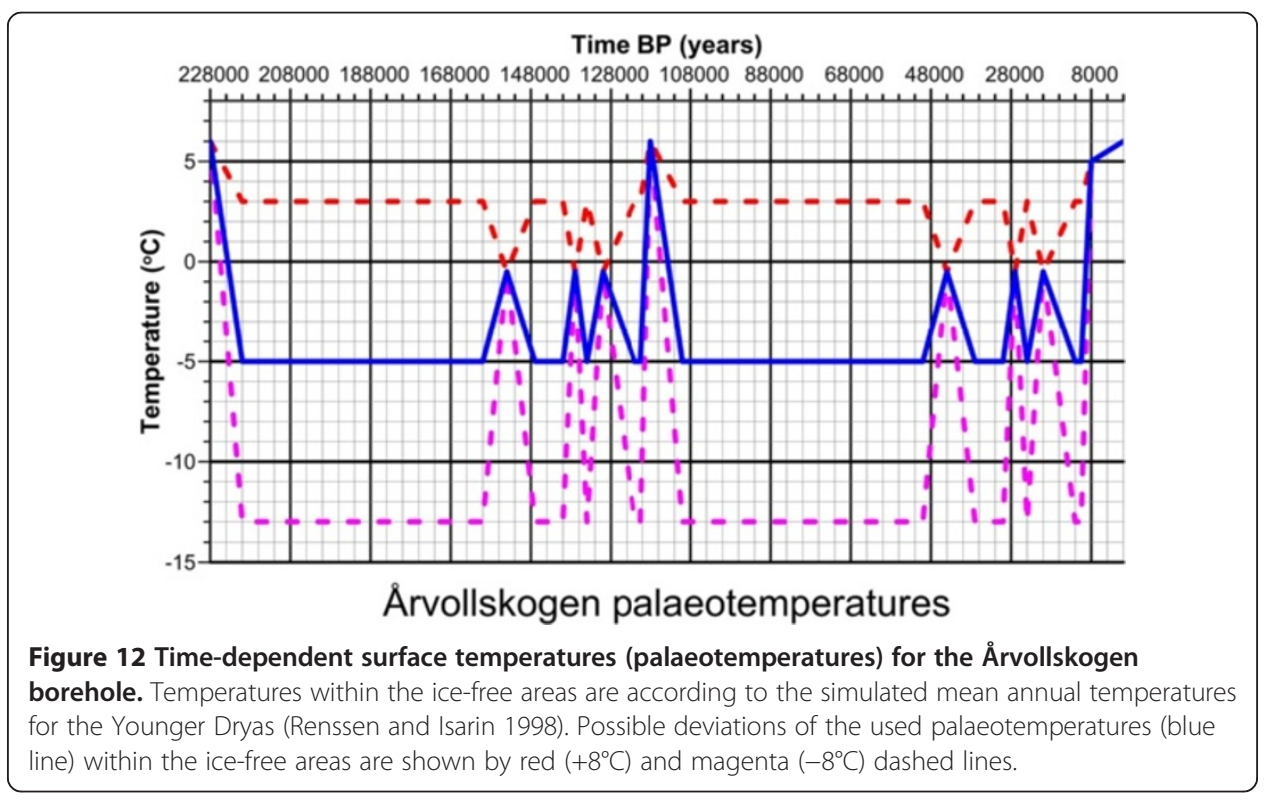


Table 2 Time-dependent surface temperatures (palaeotemperatures) for the Årvollskogen borehole

\begin{tabular}{|c|c|c|}
\hline $\begin{array}{l}\text { Time BP } \\
\text { (years) }\end{array}$ & $\begin{array}{l}\text { Average palaeo-temperature }\left(^{\circ}\right. \\
\text { C) }\end{array}$ & $\begin{array}{l}\text { Deviations of palaeotemperature in the range } \pm 8^{\circ} \mathrm{C} l^{\circ} \\
\text { C) }\end{array}$ \\
\hline 0 & 6 & 6 \\
\hline 8000 & 5 & 5 \\
\hline 10,500 & -5 & $-13-6$ \\
\hline 12,000 & -5 & $-13-6$ \\
\hline 20,000 & -0.5 & -0.5 \\
\hline 24,000 & -5 & $-13-6$ \\
\hline 27,000 & -0.5 & -0.5 \\
\hline 30,000 & -5 & $-13-6$ \\
\hline 33,000 & -5 & $-13-6$ \\
\hline 37,000 & -5 & $-13-6$ \\
\hline 44,000 & -0.5 & -0.5 \\
\hline 50,000 & -5 & $-13-6$ \\
\hline 65,000 & -5 & $-13-6$ \\
\hline 80,000 & -5 & $-13-6$ \\
\hline 90,000 & -5 & $-13-6$ \\
\hline 100,000 & -5 & $-13-6$ \\
\hline 110,000 & -5 & $-13-6$ \\
\hline 118,000 & 6 & 6 \\
\hline 120,500 & -5 & $-13-6$ \\
\hline 122,000 & -5 & $-13-6$ \\
\hline 130,000 & -0.5 & -0.5 \\
\hline 134,000 & -5 & $-13-6$ \\
\hline 137,000 & -0.5 & -0.5 \\
\hline 140,000 & -5 & $-13-6$ \\
\hline 143,000 & -5 & $-13-6$ \\
\hline 147,000 & -5 & $-13-6$ \\
\hline 154,000 & -0.5 & -0.5 \\
\hline 160,000 & -5 & $-13-6$ \\
\hline 175,000 & -5 & $-13-6$ \\
\hline 190,000 & -5 & $-13-6$ \\
\hline 200,000 & -5 & $-13-6$ \\
\hline 210,000 & -5 & $-13-6$ \\
\hline 220,000 & -5 & $-13-6$ \\
\hline 228,000 & 6 & 6 \\
\hline
\end{tabular}

western part of the magnetic map in Figure 6. On the other hand, the long-wavelength positive gravity anomaly over the axial part of the Oslo Graben could be mostly associated with the deep-seated high-density body. The presence of this body is supported by zones of increased seismic velocities within the middle crust of the Oslo Graben according to the Magnus-Rex deep seismic experiment (Stratford et al. 2009; Stratford and Thybo 2011). Therefore, the modelled, middle-lower, crustal high-density zone within the southern part of Line 1 (Figure 13) could represent the southeastern 


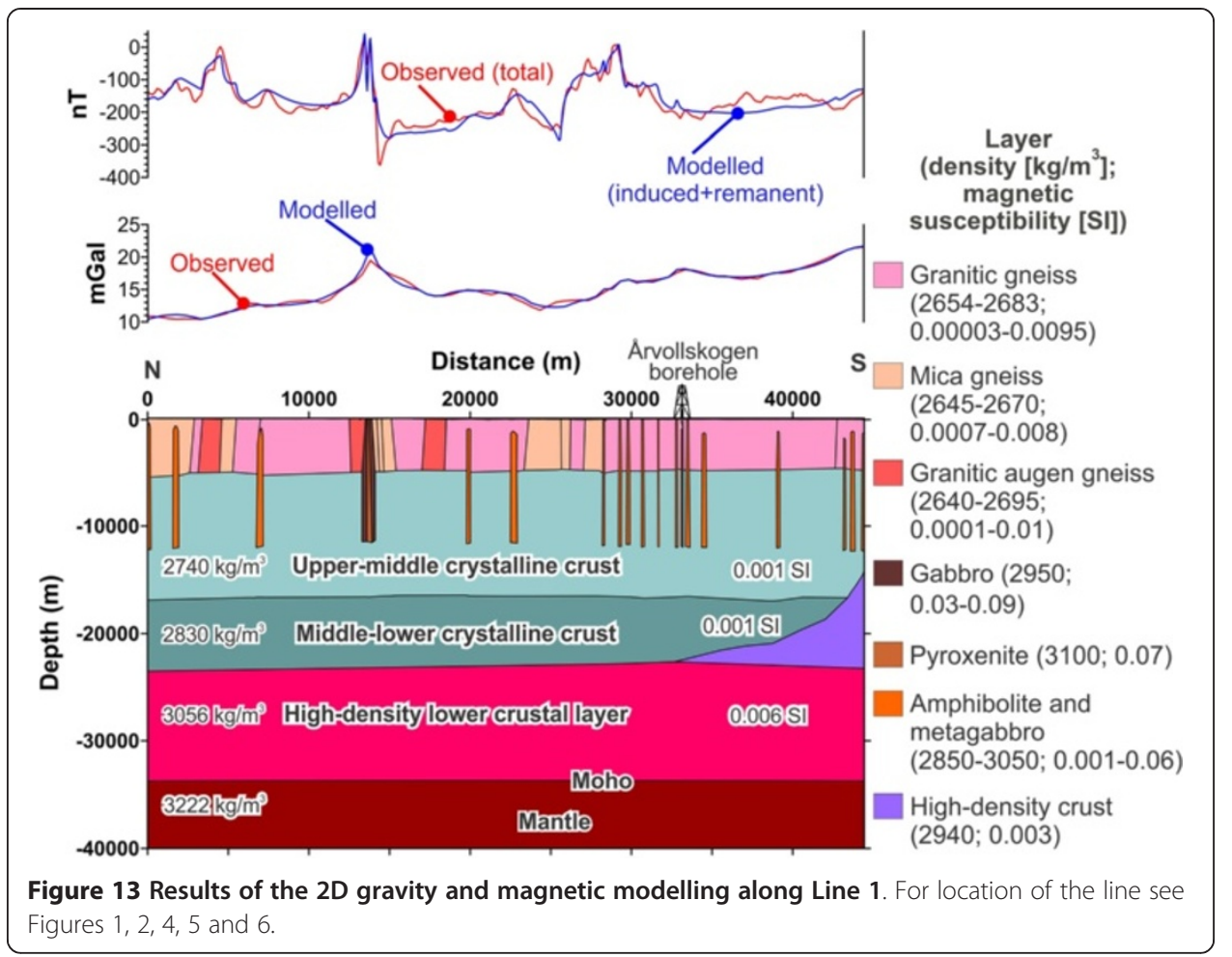

extension of the middle-lower crustal high-velocity zone beneath the central part of the Oslo Graben.

The long-wavelength component of the observed gravity anomalies is complicated by a short-wavelength positive gravity anomaly over Line 1 between 10,000 and 20,000 metres (Figure 13). In contrast to the previously described case, there is a clear correlation between this local-scale gravity anomaly and the observed magnetic anomalies (Figure 13, c.f. Figures 4 and 6). Moreover, these short-wavelength gravity and magnetic anomalies are situated over the magmatic intrusive rocks (gabbro and pyroxenite) according to the geological data (Figure 4; Lutro and Nordgulen 2008). As a result, the magmatic intrusion has been included into the upper and middle crystalline crust during the 2D crustal modelling in order to fit the observed and modelled gravity anomalies. According to the geological data, this vertically elongated intrusive body (the brown body in Line 1 in Figure 13) may have a Late Carboniferous, Permian or Early Triassic age.

In addition to the above-mentioned Upper Palaeozoic-Lower Mesozoic (possibly Early Triassic) intrusion, several smaller intrusions (orange bodies) have been included into the upper-middle crust based on the geological map (Lutro and Nordgulen 2008) and the potential field data. However, these intrusions are shown rather schematically because they are not so strongly pronounced by the observed gravity and magnetic fields as compared to the previously described intrusion. This is most likely due to the fact that these smaller intrusions are much older and are mainly represented by the Palaeo-Mesoproterozoic (meta)gabbros and metamorphosed intrusions (amphibolites). The Årvollskogen borehole is actually located within the area where the PalaeoMesoproterozoic gabbros and amphibolites are exposed at the surface and are also encountered in our borehole. In this particular case, the thickness of the drilled amphibolites is around $300 \mathrm{~m}$ within the upper part of the Årvollskogen borehole. The 
amphibolites and gabbros are definitely characterised by different thermal properties compared to the surrounding granitic gneisses and, for that reason, these rocks have been included into the $2 \mathrm{D}$ crustal model in order to enhance the accuracy of the 2D conductive thermal modelling. On the other hand, the detailed geometry of these intrusions is somewhat uncertain.

For the final fit of the observed and modelled gravity and magnetics, the upper crust has been subdivided into several blocks with slightly different densities and varying magnetic susceptibilities. This detailed structure of the upper crystalline crust has been modelled to reproduce the short-wavelength components of the observed gravity and magnetic fields, indicating the presence of upper-crustal blocks with varying densities and magnetic properties. The latter, together with the geological data (Lutro and Nordgulen 2008), demonstrate that the lithological composition of the upper-crustal layer varies spatially and, therefore, the thermal properties of the upper-crustal rocks can vary as well.

\section{Results of $2 \mathrm{D}$ conductive thermal modelling}

The final step of our integrated study concerns 2D thermal simulations, which have been performed to understand the thermal pattern of the subsurface beneath the Moss area. The obtained 2D crustal model along Line 1 (Figure 13), consistent with the gravity and the magnetics, has been used as a structural skeleton during the $2 \mathrm{D}$ conductive thermal modelling. A number of testing models have been generated and validated during the $2 \mathrm{D}$ thermal modelling in order to simulate a fit between the measured and the modelled temperatures in the Årvollskogen borehole.

The starting point of the 2D thermal modelling was an initial thermal model that has been calculated without consideration of the palaeoclimatic corrections. The annual average air temperature during the period 1961-1990 (Tveito et al. 2000) near the location of the Årvollskogen borehole has been used for the upper thermal boundary at the Earth's surface (Figure 4). In particular, a constant temperature of $6.2^{\circ} \mathrm{C}$ has been applied during the initial 2D thermal modelling at the surface within the Moss area. The lithosphere-asthenosphere boundary (Figure 8b; Gradmann et al. 2013) has been taken as a lower thermal boundary, which corresponds approximately to the $1300^{\circ} \mathrm{C}$ isotherm (e.g., Turcotte and Schubert 2002).

The calculated distribution of temperatures with depth in the Årvollskogen borehole is shown in Figure 14. The modelled temperatures have been carefully compared with the measured temperatures in the Årvollskogen borehole. The result of the comparison demonstrates (Figure 14) that, as expected, there is a relatively big misfit between the measured temperature-depth plot and the results of the modelling. This misfit is more than $4^{\circ} \mathrm{C}$ at a depth of $800 \mathrm{~m}$. Within the uppermost $10-20 \mathrm{~m}$ of the borehole, the large misfit is caused by the seasonal changes of present-day surface temperatures.

According to Kukkonen (1989), Popov et al. (1999), Slagstad et al. (2009), Kukkonen et al. (2010) and others, the significant changes in the shallow temperatures can be related to palaeoclimatic effects and/or advective cooling due to groundwater flow. In the case of the Moss area, drilling and logging in the Årvollskogen borehole indicate the presence of a number of fracture zones. On the other hand, the continuous character of the measured temperature-depth plot is characterised by an absence of large peaks 
related to strong groundwater flow (Figure 14). Therefore, the influence of only the palaeoclimatic changes has been considered in the present study, following the modified assumptions suggested by Slagstad et al. (2009). The correction made to heat flow for palaeoclimate can reach up to $25 \mathrm{~mW} / \mathrm{m}^{2}$ in the Årvollskogen borehole, and is

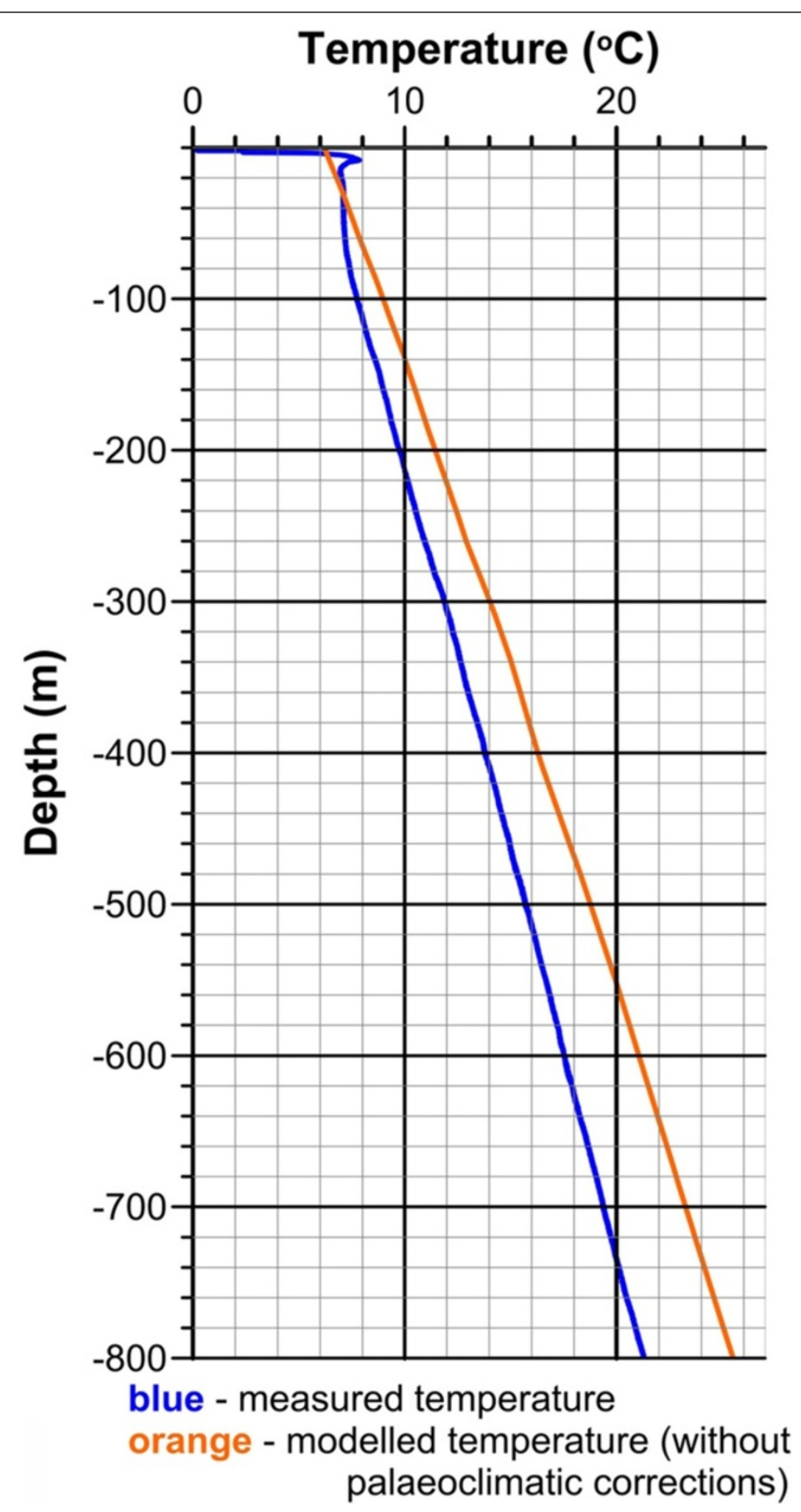

Figure 14 The Årvollskogen borehole: measured versus modelled temperatures. Modelled temperatures (orange line) are calculated without palaeoclimatic corrections. 
generally around $20 \mathrm{~mW} / \mathrm{m}^{2}$ according to the European-scale estimation by Majorowicz and Wybraniec (2010) within this part of Scandinavia. Palaeoclimatic corrections of heat flow are also relatively high in the British Isles, ranging from 13.4 to $28.2 \mathrm{~mW} /$ $\mathrm{m}^{2}$ (Westaway and Younger, 2013). Therefore, palaeoclimatic corrections can significantly change the uppermost thermal pattern within the study area.

The 2D thermal modelling has been performed with taking into account a fall in the air and ground temperatures during the Eemian and Weichselian glaciations (Figure 12 and Table 2). The results of the 2D thermal modelling, taking into account the palaeoclimatic corrections, are displayed in Figure 15, showing the 2D distribution of the modelled temperatures, heat flow and thermal gradients. The calculated distribution of temperatures along Line 1 within the Moss area is characterised by almost horizontal modelled isotherms (Figure 15a), reflecting the predominance of subhorizontal layering within the crystalline crust (Figure 13). The modelled heat flow (Figure 15b) and thermal gradient (Figure 15c) along Line 1 are characterised by a subhorizontal pattern without any considerable vertical disturbances. The modelled heat flow locally reaches more than $70 \mathrm{~mW} / \mathrm{m}^{2}$ within the uppermost crust. On the other hand, deep heat flow at the Moho level is only around $33 \mathrm{~mW} / \mathrm{m}^{2}$. Therefore, there is, as expected, a general decrease of heat-flow values with depth. This kind of heat-flow pattern is a result of the fact that the crystalline crust is characterised by an increased content of radiogenic elements compared to the lithospheric mantle (Table 1) and, for that reason, the crystalline crust acts as an additional heat source, contributing essentially to a deep heat flow from the Earth's interior. Furthermore, the calculated heat flow and thermal gradient are characterised by the presence of a clearly recognisable zone with reduced values within the uppermost part of the $2 \mathrm{D}$ model in Figures $15 \mathrm{~b}, \mathrm{c}$. This effect is related to an influence of the palaeoclimatic changes of the surface temperature during the last glaciations (Figure 12). The calculated thermal gradient is generally in agreement with the measured thermal gradient in the Årvollskogen borehole which is on average $19.3^{\circ} \mathrm{C} / \mathrm{km}$.

The comparison of modelled and measured temperature-depth plots (Figure 16) demonstrates a very good fit in the case when the palaeoclimatic perturbations (Figure 12) have been considered during the $2 \mathrm{D}$ thermal simulations. Results of the $2 \mathrm{D}$ thermal modelling for greater depths (Figure 17) demonstrate that the modelled temperature is around $120^{\circ} \mathrm{C}$ at a depth of $5000 \mathrm{~m}$, around $141^{\circ} \mathrm{C}$ at a depth of $6000 \mathrm{~m}$ and $100^{\circ} \mathrm{C}$ isotherm has been modelled at around a depth of $4130 \mathrm{~m}$.

\section{Discussion}

It is obvious that various density, magnetic and structural models can independently reproduce the observed gravity or magnetic fields. Therefore, we have to consider the inherent non-uniqueness of the methodology. During this investigation, most of the limitations of the approach have been drastically reduced by use of additional constraining structural data. Sensitivity analysis demonstrates that the modelled gravity response is mainly sensitive to modifications of the layer's geometry at the interfaces where a strong density contrast is present, such as internal crustal boundaries, the Moho discontinuity and the lithosphere-asthenosphere boundary. For instance, at a depth of 4500-5500 m, the modelled lithological change in the crust is supported by seismic data (Stratford and Thybo 2011). At this depth there is a P-wave velocity change from $5560-6030 \mathrm{~m} / \mathrm{s}$ in the upper layer to more than $6100 \mathrm{~m} / \mathrm{s}$ below this layer. 


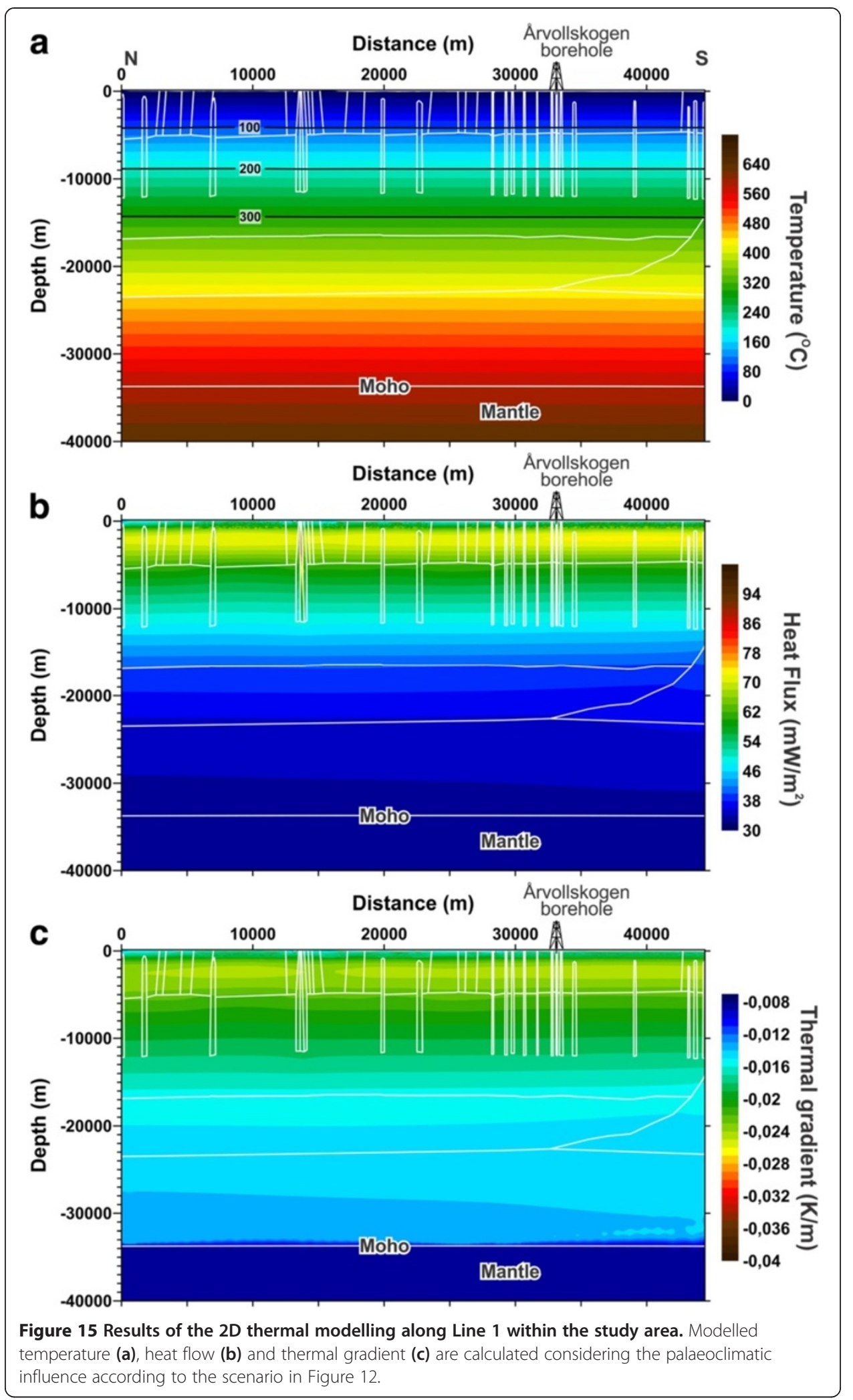




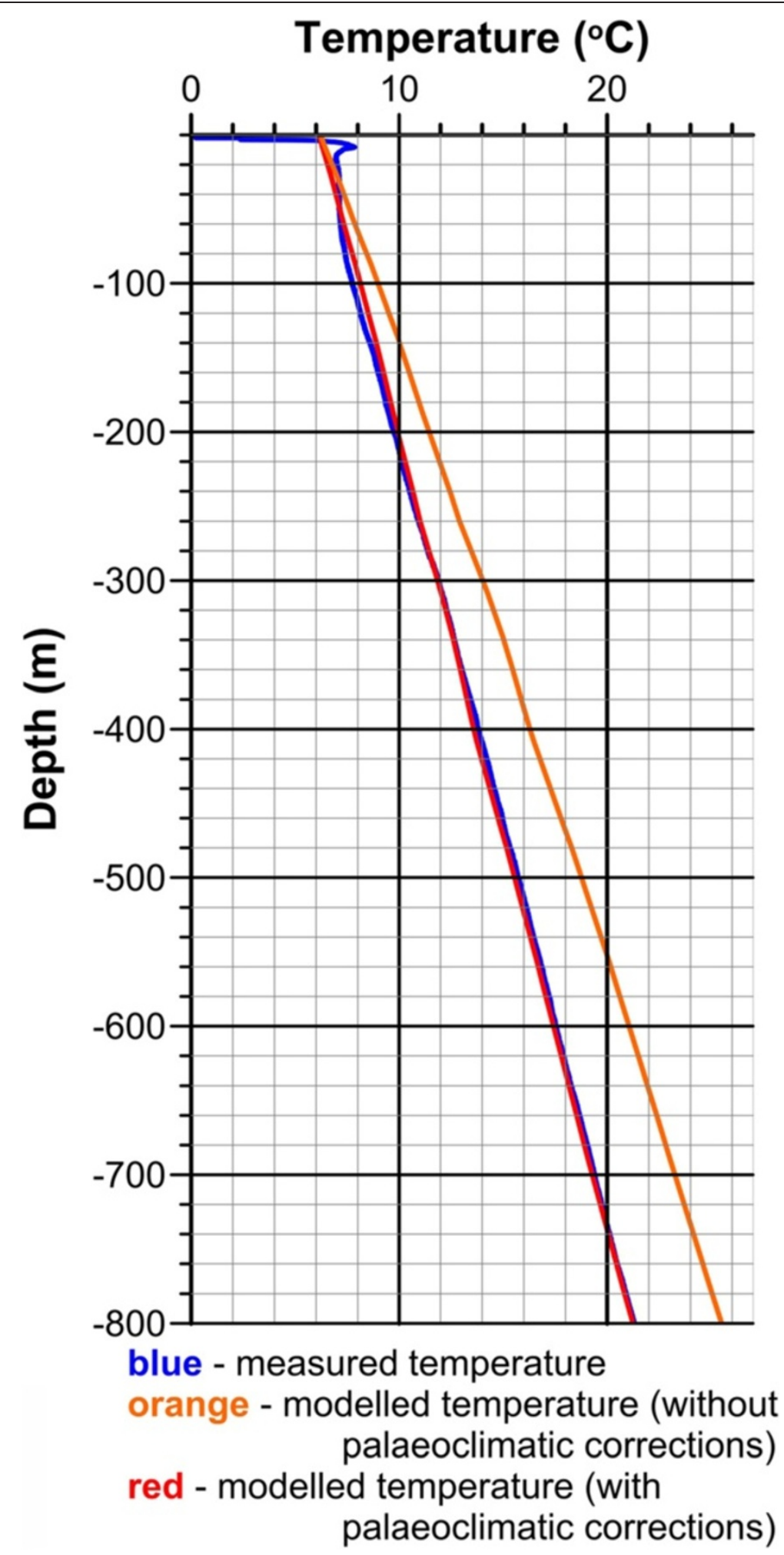

Figure 16 The Årvollskogen borehole: measured versus modelled temperatures. The orange line is assuming steady-state conditions and the red one is with taking into account palaeoclimatic corrections. 
This difference in seismic velocity is reflected by $2 \mathrm{D}$ density modelling which indicates changes of average densities from $2645-2695 \mathrm{~kg} / \mathrm{m}^{3}$ to $2740 \mathrm{~kg} / \mathrm{m}^{3}$ within this part of the upper crust (Figure 13). Furthermore, the depth position of the Moho is well constrained by deep seismic data over large parts of the modelled area (Figure 1, 6a; Stratford et al. 2009, Stratford and Thybo 2011). The uncertainties in geometry, densities and magnetic properties actually increase with depth as a result of the decreasing resolution of the input data. This point is especially relevant for the depth to the lithosphereasthenosphere boundary which is the deepest boundary of the model and at the same time the lower thermal boundary. To remove all uncertainties, additional data would be required which we do not have at the moment. Alternatively, the influence of the probable uncertainties in the depth of the lithosphere-asthenosphere boundary can be examined.

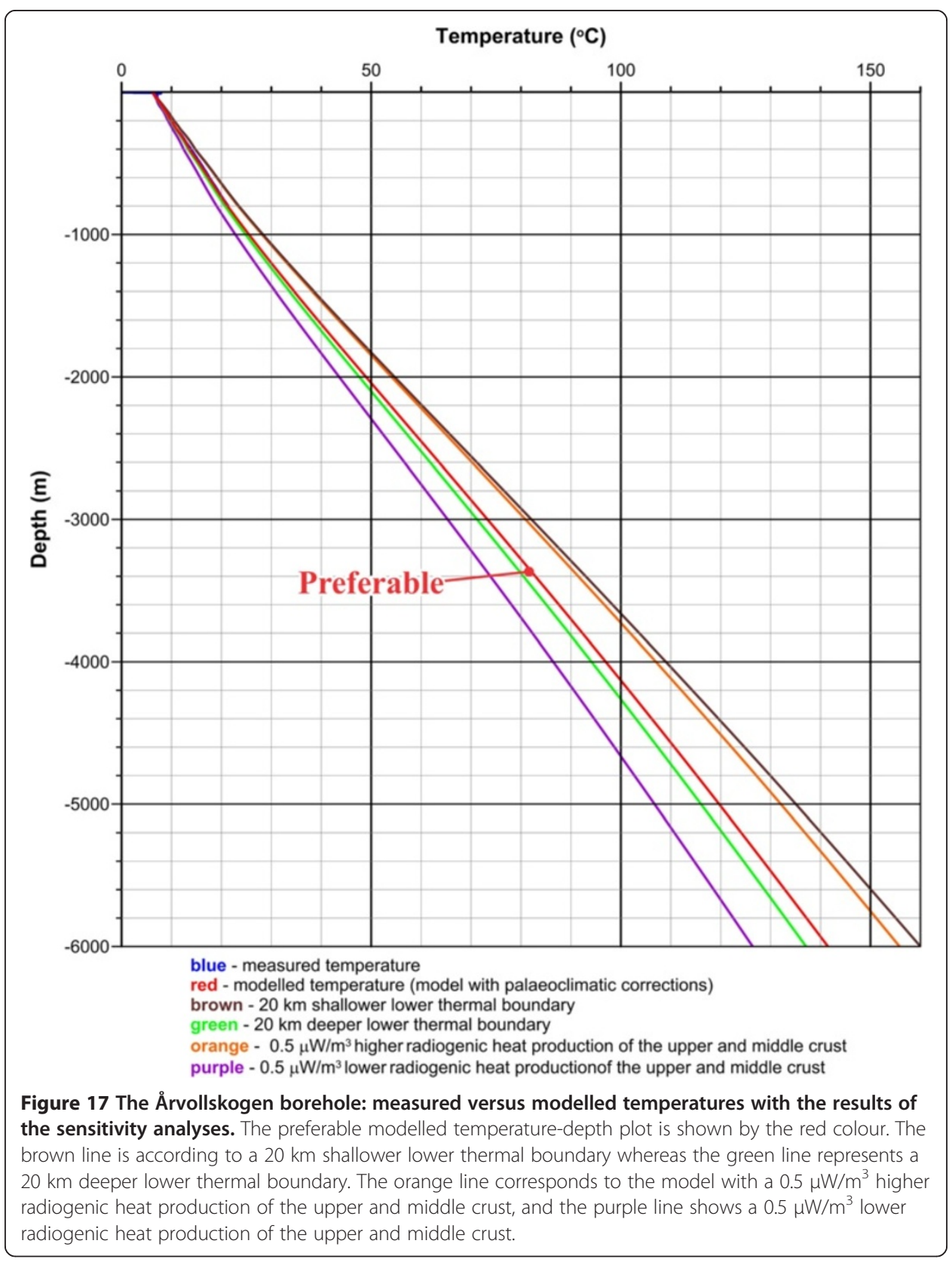


The modelled temperatures for two possible cases with a 20,000 $\mathrm{m}$ shallower and a 20,000 $\mathrm{m}$ deeper base of the lithosphere have been calculated in addition to our preferred configuration of the lower thermal boundary in Figure 8b. Furthermore, 2D thermal models with reduced and increased values of the radiogenic heat production within the upper and middle crust have also been evaluated. The reduction and increase of the radiogenic heat production have been chosen to be equal to $0.5 \mu \mathrm{W} / \mathrm{m}^{3}$, representing an influence of possible variations of the radiogenic heat production within the upper and middle crust of the Moss area at the regional scale. The position of the lower thermal boundary controls the distance to a deep heat from the Earth's interior, which is one of the main heat sources in the 2D thermal model, and the radiogenic heat production of the upper and middle crust represents the largest source of heat in the model in addition to the internal heat of the Earth. Therefore, the influence of two major factors, such as (1) the vertical position of the lower thermal boundary and (2) the radiogenic heat production within the middle-upper crystalline crust, which control the pattern and magnitude of heat flow, have been examined, allowing us to estimate the first-order uncertainty of the modelled temperature. The results of the sensitivity analysis (Figure 17) indicate that the differences in temperatures strongly increase with depth, reaching deviations of the modelled temperature of about $\pm 12 \%$ down to a depth of $6000 \mathrm{~m}$.

\section{Conclusions}

The regional structure of the upper crust is relatively complex, reflecting the longlasting tectonic evolution since Palaeoproterozoic time when the majority of the gneissic crystalline rocks of the Moss area were formed. The results of the 2D density and magnetic modelling indicate that the crystalline crust is characterised by subhorizontal layering which is strongly complicated by the presence of the magmatic intrusions within the upper part of the crystalline crust (Figure 13).

Based on the gravity- and magnetic-consistent structural background, the modelled temperature in the subsurface of the Moss area reflects the interaction between the thermal properties of the rocks and the deep heat flow from the base of the lithosphere. At great depths, the limited information that we have about the thermal properties of rocks implies that the chosen values of the radioactive heat production, thermal conductivity and specific heat capacity can vary within a reasonable range and, therefore, the modelled temperature-depth profile can deviate from the obtained values (Figure 15a). The thermal effects of changes of the thermal properties and the depth position of the lithosphere-asthenosphere boundary have been examined, showing that the deviations of the modelled temperature are around $\pm 12 \%$ at a depth of $6000 \mathrm{~m}$. It should be mentioned that if more than one parameter (radiogenic heat production, depth to the lithosphereasthenosphere boundary, thermal conductivity, etc.) does not fit the predicted range of values, the differences can increase to more than $12 \%$ in total. On the other hand, the relative stability of the results is supported by a coincidence between the calculated and the measured temperatures in the Årvollskogen borehole when the palaeoclimatic corrections are considered (Figure 16).

The effect of the palaeoclimatic changes on the surface temperature is relatively great within the Moss area, which was affected by two separate glaciations (Saalian and Weichselian glacial periods) during the last 228,000 years. 
In summary, it can be stated that the modelled temperatures in the Moss borehole are within a reasonable range of values which would be expected within the eastern flank of the Oslo Graben, according to available information about the structure of the study area.

\section{Nomenclature}

\section{NGU: Geological Survey of Norway (Norges geologiske undersøkelse).}

\section{Competing interests}

The authors declare that they have no competing interests.

\section{Authors' contributions}

MYP performed the 2D density, magnetic and thermal modelling, made the scientific analysis and interpretation of the obtained results and wrote the greater part of the text, HKE carried out the data acquisition (thermal, natural gamma and gamma spectrometry logging in the borehole), GVG performed the lithological characterization of the drillcore and sampling. The NGU laboratory was responsible for measurements of densities, thermal conductivities and specific heat capacities, OL assisted with the geology of the study area and described the lithologies in the borehole, OO participated in the 2D modelling and was deeply involved in all discussions, JSR supervised the project, participated in text writing and discussed the results. All authors participated in the discussing the results and in approval of the manuscript.

\section{Acknowledgements}

The authors are grateful to Statkraft Varme AS (and Torbjørn Mehli in particular) for the initiation and support of this study within the framework of the project "Evaluation of the deep geothermal potential in Moss area, Østfold county". We would also like to thank Statkraft Varme AS for permission to publish the obtained results, and colleagues in the NGU laboratory for performing the analyses. We appreciate the helpful reviews and suggestions provided by two anonymous reviewers. Special thanks to David Roberts for improvement of English.

Received: 2 August 2014 Accepted: 12 November 2014

Published online: 23 December 2014

\section{References}

Andersen BG, Borns JHW (1994) The Ice Age World. Scandinavian University Press (Universitetsforlaget AS), Oslo Artemieva IM (2006) Global $1^{\circ} \times 1^{\circ}$ thermal model TC1 for the continental lithosphere: Implications for lithosphere secular evolution. Tectonophysics 416:245-277

Artemieva IM, Thybo H, Kaban MK (2006) Deep Europe Today: Geophysical Synthesis of the Upper Mantle Structure and Lithospheric Processes Over 3.5 Ga. In: Gee DG, Stephenson RA (eds) European Lithosphere Dynamics, Geol Soc London Mem. the Geological Society Publishing House, Bath, doi: 10.1144/GSL.MEM.2006.032.01.02

Baldschuhn R, Binot F, Fleig S, Kockel F (2001) Geotektonischer Atlas von Nordwest-Deutschland und dem deutschen Nordsee-Sektor - Strukturen, Struckurenwicklung, Paläogeographie. Geologisches Jahrbuch A 153:1-88, 3 CD-Rs

Barton PJ (1986) The relationship between seismic velocity and density in the continental crust - a useful constraint? Geophys J R Astron Soc 87:195-208, doi:10.1111/j.1365-246X.1986.tb04553.x

Calcagnile G (1982) The lithosphere-asthenosphere system in Fennoscandia. Tectonophysics 90:19-35

Čermak V, Rybach L (1982) Thermal Properties: Thermal Conductivity and Specific Heat of Minerals and Rocks. In: Angenheister G (ed) Landolt-Börnstein, New Series, Geophysics and space research Volume 1: 305-343, subvolume A. Springer, Berlin

Clauser C (2011) Thermal Storage and Transport Properties of Rocks. In: Gupta H (ed) Heat capacity and latent heat, Encyclopedia of Solid Earth's Geophysics, vol Volume 2, 2nd edn., pp 1423-1431

Davis BAS, Brewer S, Stevenson AC, Guiot J, Contributors D (2003) The temperature of Europe during the Holocene reconstructed from pollen data. Quat Sci Rev 22(15-17):1701-1716

Ebbing J, Skilbrei JR, Olesen O (2007) Insights into the magmatic architecture of the Oslo Graben by petrophysically constrained analysis of the gravity and magnetic field. J Geophys Res 112, B04404, doi:10.1029/2006JB004694

Ebbing J, England R, Korja T, Lauritsen T, Olesen O, Stratford W, Weidle C (2012) Structure of the Scandes lithosphere from surface to depth. Tectonophysics 536-537:1-24, doi:10.1016/j.tecto.2012.02.016

Fichler C, Odinsen T, Rueslåtten H, Olesen O, Vindstad JE, Wienecke S (2011) Crustal inhomogeneities in the Northern North Sea from potential field modeling: Inherited structure and serpentinites? Tectonophysics 510:172-185

Fugro Airborne Surveys (2003) Logistics report, fixed-wing borne magnetic, radiometric and VLF-EM survey in the Oslo region, southern Norway. Report FCR 2241

Gellein J, Olesen O, Reitan M, Sæther PO (1993) Brukerbeskrivelse - database og prosessering av gravimetriske data. NGU Internrapport 93:019

Gradmann S, Ebbing J, Fullea J (2013) Integrated geophysical modelling of boundary zone in lithospheric mantle under Norway and Sweden. Geophys J Int 194(3):1358-1373

Heeremans M, Faleide II (2004) Permo-Carboniferous rifting in the Skagerrak, Kattegat and the North Sea: evidence from seismic and borehole data. In: Wilson M, Neumann E-R, Davies G, Timmerman MJ, Heeremans M, Larsen BT (eds) Permo-Carboniferous Magmatism and Rifting in Europe, vol 223. Geological Society London Special Publications, London, United Kingdom, pp 157-176 
Hofmeister AM (1999) Mantle values of thermal conductivity and the geotherm from phonon lifetimes. Science 283:1699-1706

Kukkonen IT (1989) Terrestrial heat flow and radiogenic heat production in Finland, the central Baltic Shield. Tectonophysics 164:219-230

Kukkonen IT, Rath V, Kivekäs L, Šafanda J, Čermak V (2010) Geothermal studies of the Outokumpu Deep Drill Hole, Finland: Vertical variation in heat flow and palaeoclimatic implications. Phys Earth Planet Inter 188:9-25

Larsen BT, Olaussen S, Sundvoll B, Heeremans M (2008) The Permo-Carboniferous Oslo Rift through six stages and 65 million years. Episodes 31(1):52-58

Lokhorst A (1998) The Northwest European GasAtlas. Netherlands Institute of Applied Geoscience TNO, Haarlem, the Netherlands

Lutro O, Nordgulen Ø (2008) Oslofeltet, berggrunnskart M 1: 250,000. Norges geologiske undersøkelse

Majorowicz J, Wybraniec S (2010) New terrestrial heat flow map of Europe after regional palaeoclimatic correction application. Int J Earth Sci doi:10.1007/s00531-010-0526-1

Maystrenko YP, Scheck-Wenderoth M (2013) 3D lithosphere-scale density model of the Central European Basin System and adjacent areas. Tectonophysics 601:53-77, doi:10.1016/j.tecto.2013.04.023

Maystrenko YP, Bayer U, Scheck-Wenderoth M (2012) Regional-scale structural role of Permian salt within the Central European Basin System. In: Alsop GI, Archer SG, Hartley AJ, Grant NT, Hodgkinson R (eds) Salt Tectonics, Sediments and Prospectivity, vol 363. Geological Society London Special Publications, London, United Kingdom, pp 409-430, doi: $10.1144 / S P 363.19$

Medhus AB, Balling N, Jacobsen BH, Kind R, England RW (2009) Deep-structural differences in southwestern Scandinavia revealed by P-wave travel time residuals. Nor J Geol 89:203-214

Neumann E-R, Wilson M, Heeremans M, Spencer EA, Obst K, Timmerman MJ, Kirstein L (2004) Carboniferous-Permian rifting and magmatism in southern Scandinavia, the North Sea and northern Germany: a review. In: Wilson M, Neumann E-R, Davies G, Timmerman MJ, Heeremans M, Larsen BT (eds) Permo-Carboniferous Magmatism and Rifting in Europe, vol 223. Geological Society London Special Publications, London, United Kingdom, pp 1-10

Olesen O, Reitan M, Sæther PO (1993) Petrofysisk database PETBASE 3.0, Brukerbeskrivelse, NGU Internrapport 93.023

Olesen O, Balling N, Barrère C, Breiner N, Davidsen B, Ebbing J, Elvebakk H, Gernigon L, Koziel J, Lutro O, Midttømme K, Nordgulen Ø, Olsen L, Osmundsen PT, Pascal C, Ramstad RK, Rønning JS, Skilbrei JR, Slagstad T, Wissing B (2007) KONTIKI final report, continental crust and heat generation in 3D. NGU Report 2007:042

Olesen O, Brönner M, Ebbing J, Gellein J, Gernigon L, Koziel J, Lauritsen T, Myklebust R, Sand M, Solheim D, Usov S (2010) New aeromagnetic and gravity compilations from Norway and adjacent areas - methods and applications. Petroleum Geology Conference Series 7:559-586

Olsen L (2006) Fennoscandia M-LWeichselian glacial variations - much more than just local ice-margin fluctuations. In: Peltonen P, Pasanen A (eds) The 27th Nordic Geological Wintermeeting. Bulletin of the Geological Society of Finland, Special Issue. Geological Society of Finland, Oulu, Finland, p 118

Olsen L, Sveian H, Ottesen D, Rise L (2013) Quaternary glacial, interglacial and interstadial deposits of Norway and adjacent onshore and offshore areas. In: Olsen L, Fredin O, Olesen O (eds) Quaternary Geology of Norway, vol 13. Geological Survey of Norway Special Publication, Trondheim, Norway, pp 79-144

Pascal C, Aarseth M, Ebbing J, Lauritsen T, Lutro O, Olesen O (2010a) Quantitative assessment of geothermal resources in the Oslo and Bergen regions. NGU Report 2010:054

Pascal C, Barrère C, Davidsen B, Ebbing J, Elvebakk H, Mesli M, Roberts D, Slagstad T, Wissing B (2010b) HeatBear Final Report 2010, Basement Heat Generation and Heat Flow in the western Barents Sea - Importance for hydrocarbon systems. NGU Report 2010:030

Pattyn F (2010) Antarctic subglacial conditions inferred from a hybrid ice sheet/ice stream model. Earth's Planet Sci Lett 295:451-461

Pharaoh TC (1999) Palaeozoic terranes and their lithosphere boundaries within the Trans-European Suture Zone (TESZ): a review. Tectonophysics 314:17-41, doi:10.1016/S0040-1951(99)00235-8

Popov YA, Pevzner SL, Pimenov VP, Romushkevich RA (1999) New geothermal data from the Kola superdeep well SG-3. Can Geotech J 306(3-4):345-366

Renssen H, Isarin RFB (1998) Surface temperature in NW Europe during the Younger Dryas: AGCM simulation compared with temperature reconstructions. Clim Dyn 14:33-44

Ro HE, Larsson FR, Kinck JJ, Husebye ES (1990) The Oslo Rift-its evolution on the basis of geological and geophysical observations. Tectonophysics 178:11-28

Rønning JS, Dalsegg E, Elvebakk H, Ganerød GV, Lutro O, Maystrenko Y, Olesen O (2013) Evaluation of the deep geothermal potential in Moss area, Østfold county. NGU Report 2013:008

Rybach L (1988) Determination of heat production rate. In: Hänel R, Rybach L, Stegena L (eds) Handbook of Terrestrial Heat-Flow Determination. Kluwer Academic Publishers, Dordrecht, pp 125-142

Sass JH, Lachenbruch AH, Moses TH Jr, Morgan T (1992) Heat flow from a scientific research well at Cajon Pass, California. J Geophys Res 97(B4):5017-5030

Scheck-Wenderoth M, Maystrenko Y (2008) How warm are passive continental margins? A 3D lithosphere-scale study from the Norwegian margin. Geology 36(5):419-422

Scheck-Wenderoth M, Maystrenko YP (2013) Deep control on shallow heat in sedimentary basins. Energy Procedia 40:266-275, doi.org/10.1016/j.egypro.2013.08.031

Sigmond EMO (2002) Geological Map, Land and Sea Areas of Northern Europe, Scale 1: 4 Million, Geological Survey of Norway

Slagstad T (2008) Radiogenic heat production of Archaean to Permian geological provinces in Norway. Nor J Geol 88:149-166

Slagstad T, Barrère C, Davidsen B, Ramstad RK (2008a) Petrophysical and thermal properties of pre-Devonian basement rocks on the Norwegian continental margin. Geological Survey of Norway, Bulletin 448:1-6

Slagstad T, Midttømme K, Ramstad RK, Slagstad D (2008b) Factors influencing shallow ( $<1000 \mathrm{~m}$ depth) temperatures and their significance for extraction of ground-source heat. In: Slagstad T (ed) Geology for Society, Geological Survey of Norway Special Publication, vol 11., pp 99-109 
Slagstad T, Balling N, Elvebakk H, Midttømme K, Olesen O, Olsen L, Pascal C (2009) Heat-flow measurements in Late Palaeoproterozoic to Permian geological provinces in south and central Norway and a new heat-flow map of Fennoscandia and the Norwegian-Greenland Sea. Tectonophysics 473:341-361

Stratford W, Thybo H (2011) Crustal structure and composition of the Oslo Graben, Norway. Earth Planet Sci Lett 304:431-442

Stratford W, Thybo H, Faleide Jl, Olesen O, Tryggvason A (2009) New Moho Map for onshore southern Norway. Geophys J Int 178:1755-1765, doi:10.1111/j.1365-246X.2009.04240.x

Turcotte DL, Schubert G (2002) Geodynamics (2nd edition): Cambridge. Press, Cambridge University

Tveito OE, Førland E, Heino R, Hanssen-Bauer I, Alexandersson H, Dahlström B, Drebs A, Kern-Hansen C, Jónsson T, Vaarby Laursen E, Westman Y (2000) Nordic temperature maps. DNMI-Report 09/00 KLIMA

van den Berg AP, Yuen DA, Steinbach V (2001) The effects of variable thermal conductivity on mantle heat-transfer. Geophys Res Lett 28:875-878

Vejbaek OV, Britze P (1994) Geological map of Denmark 1: 750,000. Top pre-Zechstein (two-way traveltime and depth). Sub- and supercrop map, Geological Survey of Denmark, Map Series 45

Vosteen H-D, Schellschmidt R (2003) Influence of temperature on thermal conductivity, thermal capacity, and thermal diffusivity for different types of rock. Phys Chem Earth 28(9-11):499-509

Westaway R, Younger PL (2013) Accounting for palaeoclimate and topography: a rigorous approach to correction of the British geothermal dataset. Geothermics 48:31-51

Wollenberg HA, Smith AR (1987) Radiogenic heat production of crustal rocks: an assessment based on geochemical data. Geophys Res Lett 14(3):295-298

Ziegler P (1990) Geological atlas of western and central Europe, 2nd edn. Shell Internationale Petroleum Maatschappij $B V$, the Netherlands, the Hague

doi:10.1186/s40517-014-0015-z

Cite this article as: Maystrenko et al:: 2D structural and thermal models in southeastern Norway based on the recently drilled Årvollskogen borehole and 2D density, magnetic and thermal modelling. Geothermal Energy 2014 2:15.

\section{Submit your manuscript to a SpringerOpen ${ }^{\circ}$ journal and benefit from:}

- Convenient online submission

Rigorous peer review

- Immediate publication on acceptance

- Open access: articles freely available online

- High visibility within the field

Retaining the copyright to your article

Submit your next manuscript at $\boldsymbol{\sim}$ springeropen.com 